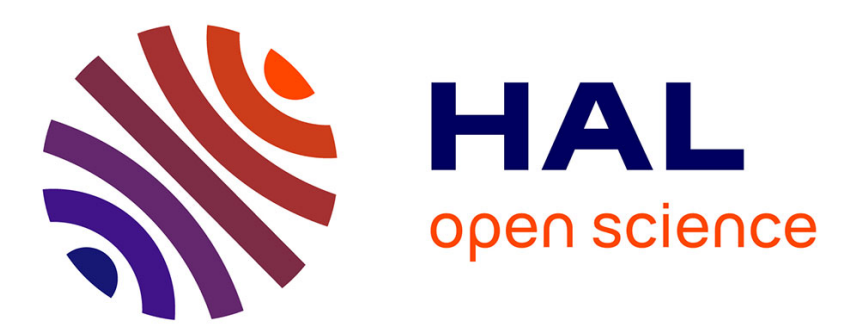

\title{
Is protein deuteration beneficial for proton detected solid-state NMR at and above $100 \mathrm{kHz}$ magic-angle spinning?
}

Diane Cala - de Paepe, Jan Stanek, Kristaps Jaudzems, Kaspars Tars, Loren B Andreas, Guido Pintacuda

\section{To cite this version:}

Diane Cala - de Paepe, Jan Stanek, Kristaps Jaudzems, Kaspars Tars, Loren B Andreas, et al.. Is protein deuteration beneficial for proton detected solid-state NMR at and above $100 \mathrm{kHz}$ magic-angle spinning?. Solid State Nuclear Magnetic Resonance, 2017, 87, pp.126-136. 10.1016/j.ssnmr.2017.07.004 . hal-01575517

\section{HAL Id: hal-01575517 \\ https://hal.science/hal-01575517}

Submitted on 15 Mar 2018

HAL is a multi-disciplinary open access archive for the deposit and dissemination of scientific research documents, whether they are published or not. The documents may come from teaching and research institutions in France or abroad, or from public or private research centers.
L'archive ouverte pluridisciplinaire $\mathbf{H A L}$, est destinée au dépôt et à la diffusion de documents scientifiques de niveau recherche, publiés ou non, émanant des établissements d'enseignement et de recherche français ou étrangers, des laboratoires publics ou privés. 


\section{Is protein deuteration beneficial for proton detected solid-state NMR at and above $100 \mathrm{kHz}$ magic-angle spinning?}

Diane Cala-De Paepe, ${ }^{\mathrm{a}^{*}}$ Jan Stanek, ${ }^{\mathrm{a}^{*}}$ Kristaps Jaudzems, ${ }^{\mathrm{a}}$ Kaspars Tars, ${ }^{\mathrm{b}}$ Loren B Andreas, ${ }^{\text {a,c }}$ Guido Pintacuda ${ }^{\text {a\# }}$

${ }^{a}$ Centre de RMN à Très Hauts Champs, Institut des Sciences Analytiques (UMR 5280 - CNRS, ENS Lyon, UCB Lyon 1), Université de Lyon, 5 rue de la Doua, 69100 Villeurbanne, France

${ }^{\mathrm{b}}$ Biomedical Research and Study Centre, Rātsupītes 1, LV1067, Riga, Latvia

${ }^{c}$ Max Planck Institute for Biophysical Chemistry, Am Fassberg 11, D-37077 Göttingen, Germany

* These authors contributed equally

\# Corresponding author: guido.pintacuda@ens-Iyon.fr (Guido Pintacuda) 


\begin{abstract}
${ }^{1} \mathrm{H}$-detection in solid-state NMR of proteins has been traditionally combined with deuteration for both resolution and sensitivity reasons, with the optimal level of proton dilution being dependent on MAS rate. Here we present ${ }^{1} \mathrm{H}$-detected ${ }^{15} \mathrm{~N}$ and ${ }^{13} \mathrm{C} \mathrm{CP}$-HSQC spectra on two microcrystalline samples acquired at 60 and $111 \mathrm{kHz}$ MAS and at ultra-high field. We critically compare the benefits of three labeling schemes yielding different levels of proton content in terms of resolution, coherence lifetimes and feasibility of scalar-based 2D correlations under these experimental conditions. We observe unexpectedly high resolution and sensitivity of aromatic resonances in $2 \mathrm{D}{ }^{13} \mathrm{C}-{ }^{1} \mathrm{H}$ correlation spectra of protonated samples. Ultrafast MAS reduces or even removes the necessity of ${ }^{1} \mathrm{H}$ dilution for highresolution ${ }^{1} \mathrm{H}$-detection in biomolecular solid-state $\mathrm{NMR}$. It yields ${ }^{15} \mathrm{~N},{ }^{1} \mathrm{H}$ and ${ }^{13} \mathrm{C},{ }^{1} \mathrm{H}$ fingerprint spectra of exceptional resolution for fully protonated samples, with notably superior ${ }^{1} \mathrm{H}$ and ${ }^{13} \mathrm{C}$ lineshapes for side-chain resonances.
\end{abstract}

\title{
Graphical Abstract
}

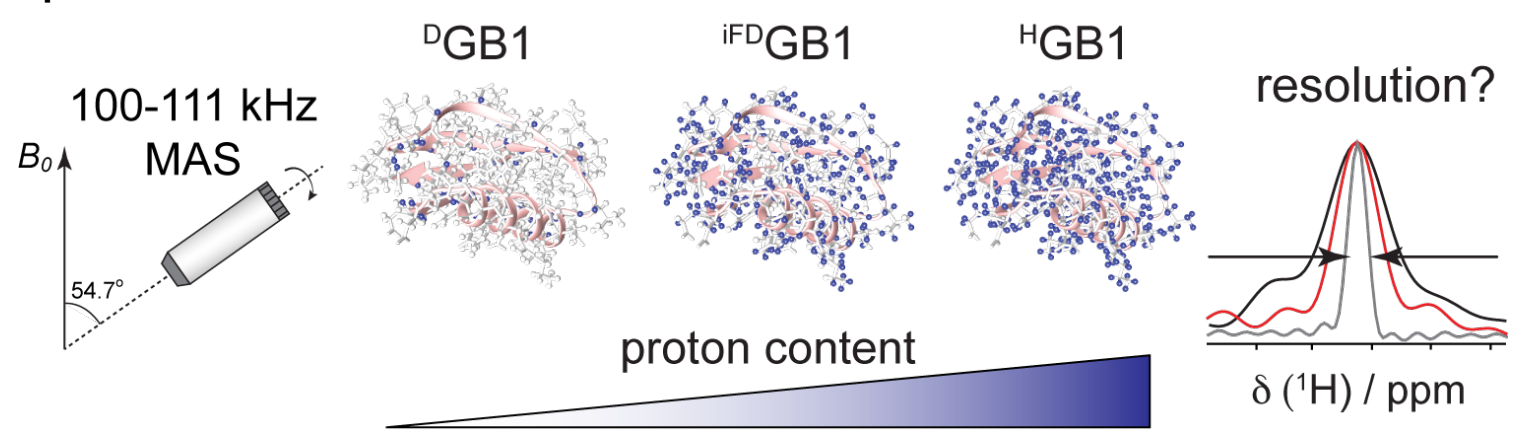

Highlights

- Fast MAS weakens ${ }^{1} \mathrm{H}$ dilution requirements for ${ }^{1} \mathrm{H}$-detection in biomolecular ssNMR

- The ${ }^{1} \mathrm{H}$ resolution enhancement due to deuteration drops with increasing MAS rate

- Proton coherence lifetime remains strongly dependent on deuteration level

- Fractional deuteration yields limited linewidth improvement at above $100 \mathrm{kHz}$ MAS

- Fully-protonated samples provide optimal ${ }^{1} \mathrm{H}$ and ${ }^{13} \mathrm{C}$ resolution for methyl resonances

\section{Keywords}

Fast magic-angle spinning, proton detection, proteins, protein assemblies, full protonation, resolution, sensitivity, side-chains, fractional deuteration, solid-state nuclear magnetic resonance

\section{Abbreviations}

${ }^{\text {D GB1 }}=\left[\mathrm{U}-{ }^{2} \mathrm{H}, \mathrm{U}-{ }^{13} \mathrm{C}, \mathrm{U}-{ }^{15} \mathrm{~N}\right]-\mathrm{GB} 1$, uniformly ${ }^{2} \mathrm{H},{ }^{13} \mathrm{C},{ }^{15} \mathrm{~N}$-labelled immunoglobulin-binding beta 1 domain of protein $\mathrm{G}$ (GB1), with $100 \%{ }^{1} \mathrm{H}$ at exchangeable sites

${ }^{\mathrm{iFD}} \mathrm{GB} 1$ = inverse fractionally deuterated $\mathrm{GB} 1,\left[{ }^{2} \mathrm{H} /{ }^{1} \mathrm{H}, \mathrm{U}-{ }^{13} \mathrm{C}, \mathrm{U}-{ }^{15} \mathrm{~N}\right]-\mathrm{GB} 1$, expressed in $\mathrm{H}_{2} \mathrm{O}$ growth medium with deuterated glucose as a sole carbon source

${ }^{\mathrm{H}} \mathrm{GB} 1=\left[\mathrm{U}-{ }^{13} \mathrm{C}, \mathrm{U}-{ }^{15} \mathrm{~N}\right]-\mathrm{GB} 1$, fully protonated, uniformly ${ }^{13} \mathrm{C},{ }^{15} \mathrm{~N}$-labelled $\mathrm{GB} 1$

${ }^{\mathrm{iFD}} \mathrm{AP205}=$ inverse fractionally deuterated AP205, $\left[{ }^{2} \mathrm{H} /{ }^{1} \mathrm{H}, \mathrm{U}-{ }^{13} \mathrm{C}, \mathrm{U}-{ }^{15} \mathrm{~N}\right]-\mathrm{AP} 205$, expressed in $\mathrm{H}_{2} \mathrm{O}$ growth medium deuterated glucose as a sole carbon source

${ }_{\text {AP205 }}=\left[\mathrm{U}-{ }^{13} \mathrm{C}, \mathrm{U}-{ }^{15} \mathrm{~N}\right]-\mathrm{AP} 205$, fully protonated, uniformly ${ }^{13} \mathrm{C},{ }^{15} \mathrm{~N}$-labelled Acinetobacter phage 205 coat protein 


\section{Introduction}

Proton detection is the most natural way to maximize sensitivity in NMR [1,2]. Protons not only have high gyromagnetic ratio, but are also abundant in biomolecules. In solids, however, this generates a dense network of homonuclear dipolar interactions, which induces significant ${ }^{1} \mathrm{H}$ line broadening at moderate magic-angle spinning (MAS), and makes ${ }^{1} \mathrm{H}$ lines prohibitive for constructive use [3].

To tackle this difficultly, MAS was originally combined with an extreme dilution of the proton content in the sample [4-6]. For most proteins, a high level of deuteration can be achieved by expression in perdeuterated media, followed by a chemical exchange of labile deuterons with protons of the solvent with a desired $\mathrm{H}_{2} \mathrm{O} / \mathrm{D}_{2} \mathrm{O}$ ratio. In the pioneering studies of Zilm and Reif, amide ${ }^{1} \mathrm{H}$ were fully reintroduced leading to a moderate resolution improvement [7, 8]. It was soon demonstrated, however, that at $10-20 \mathrm{kHz}$ MAS feasible a decade ago, higher resolution is obtained by further dilution at amide ${ }^{1} \mathrm{H}$ sites (typically $10-$ $40 \%$ [9]. The optimum deuteration level was a trade-off between higher resolution and detection sensitivity, as increased dilution results in a loss of signal of the observed nuclei $[10,11]$.

This issue has driven the development of probes capable of faster MAS, which have been increasingly more effective in averaging ${ }^{1} \mathrm{H}$ dipolar interactions [12]. Equally important is the use of very high magnetic fields which help to separate heavily overlapped resonance frequencies of interacting protons, thus reducing ${ }^{1} \mathrm{H}$ relaxation driven by spin flip-flops [13, 14]. With these hardware advancements, the proton dilution requirements have become less stringent for NMR studies at high resolution [15-17]. In particular, it was shown that sensitive cross-polarization (CP) HSQC spectra with ${ }^{1} \mathrm{H}^{\mathrm{N}}$ linewidths smaller than $100 \mathrm{~Hz}$ can be obtained for microcrystalline uniformly $\left[{ }^{2} \mathrm{H},{ }^{13} \mathrm{C},{ }^{15} \mathrm{~N}\right]$-labeled protein samples fully backexchanged at amide sites, under conditions of $60 \mathrm{kHz}$ MAS on a $1 \mathrm{GHz}$ spectrometer. Despite substantial reduction of sample amount (to $2-3 \mathrm{mg}$ for a $1.3 \mathrm{~mm}$ ) this approach yields very high sensitivity due to multiple factors as reviewed recently [13]. With the advent of even faster MAS rates in smaller rotors, larger sensitivity gains per sample volume have been reported (less than $1 \mathrm{mg}$ is required for $0.8 \mathrm{~mm}[18,19]$ and $0.7 \mathrm{~mm}[20]$ rotors).

However, chemical exchange of labile deuterons with protons severely limits observation of side-chain signals, which are essential reporters of structure, dynamics and interactions in a protein. In contrast to amide sites, introduction of protons or deuterons in side-chains can only take place during protein expression. It was first realized by the group of Reif that ${ }^{2} \mathrm{H}$ glucose used for expression is not completely ${ }^{1} \mathrm{H}$-depleted, leading to observable signal in side-chains [6, 21]. Proton occupancy at methyl sites was then increased by expression in $1: 9 \mathrm{H}_{2} \mathrm{O}: \mathrm{D}_{2} \mathrm{O}$ media using a partially protonated methyl-containing residue precursor, and high resolution ${ }^{1} \mathrm{H},{ }^{13} \mathrm{C}$-methyl correlation spectra were obtained using relaxation-filtration of isotopomers [22].

This approach was later generalized to all side-chain sites by the use of ${ }^{2} \mathrm{H},{ }^{13} \mathrm{C}$-glucose and controlled low concentration of $\mathrm{H}_{2} \mathrm{O}$ in $\mathrm{D}_{2} \mathrm{O}$ buffer $(5-15 \%)$. This labeling scheme, termed Reduced Adjoining Protonation (RAP) [23, 24], leads to a random mixture of isotopomers, however, the problem is not severe due to high imbalance of their population at low level of ${ }^{1} \mathrm{H}$ incorporation. At $20 \mathrm{kHz}$ MAS this method yielded aliphatic ${ }^{1} \mathrm{H}$ linewidths between 25 and $60 \mathrm{~Hz}$ for microcrystalline chicken alpha spectrin SH3 domain and enabled observation of some long-range ${ }^{1} \mathrm{H}-{ }^{1} \mathrm{H}$ distance restraints [23], however, dilution of ${ }^{1} \mathrm{H}$ spins inherently decreased the probability of such contacts. Slightly higher proton content (usually $10-40 \%$ ) is achieved with so-called fractional deuteration (FD), which employs protonated glucose for expression in $\mathrm{D}_{2} \mathrm{O}$ media [25], while high resolution is ensured by significantly faster spinning (about $55 \mathrm{kHz}$ ).

The proton dilution remained a major concern, since it partially offset advantages of higher sensitivity of ${ }^{1} \mathrm{H}$-detection. As possible remedy is $E$. coli protein expression with the addition of suitable metabolic precursors of I, L, V residues, developed originally for liquid-state NMR [26, 27]. This provides detached protons in methyl groups, either $\mathrm{CH}_{3}$ or $\mathrm{CHD}_{2}$, with the possibility of reduced spectral crowding by stereo- and regiospecific labeling [28]. Despite 
lower occupancy, $\mathrm{CHD}_{2}$-labelling proved more useful at about $50-60 \mathrm{kHz}$ MAS due to higher resolution and ease of obtaining ${ }^{1} \mathrm{H}-{ }^{1} \mathrm{H}$ distance restrains without dipolar truncation $[18,29]$. Recently, it has been shown that under these MAS conditions, 2-fold higher sensitivity in fingerprint ${ }^{13} \mathrm{C},{ }^{1} \mathrm{H}$-correlation spectra is obtained using $\mathrm{CH}_{3}$-labelling of either lle or Ala residues. It entails certain loss of resolution but is generally advantageous in the cases of critically low sensitivity [30].

For the majority of globular proteins, methyl protons provide tertiary contacts essential to define a protein fold with high precision [29, 31]. An alternative concept that ensures $100 \%$ site incorporation and scarcity of protons is Stereo-Array Isotope Labeling (SAIL) [32]. It offers access to all side-chain sites and considerably reduces spectral crowding due flexibility and precise control over sites of incorporation with inherent absence of scrambling. With moderate MAS rate of $27 \mathrm{kHz}, 2$ - to 7 -fold reduction of ${ }^{1} \mathrm{H}$ linewidths was observed for valine residues [33]. Due to high cost of specifically labeled amino acids, the approach necessitates the use of cell-free expression, and has not been so far widely applied. Recently, a miniaturization of MAS rotors has partly addressed this issue allowing backbone and sidechain assignment using sub-milligram quantity of SAIL-labelled protein [34].

It is also possible to incorporate specific fully protonated amino acid residues (such as valine and leucine) into otherwise deuterated matrix, the scrambling of amino acids being dependent on biosynthetic pathways in a given expression system. The concept, referred to as proton-cloud labeling [35], has been utilized to reduce ${ }^{1} \mathrm{H}$ linewidths by a factor of 2 to 3 w.r.t. a fully protonated microcrystalline sample of ubiquitin at $60 \mathrm{kHz}$ MAS.

Except SAIL, all methods described above lean on expression in highly concentrated $\mathrm{D}_{2} \mathrm{O}$, which reduces the protein yield in bacteria and is incompatible with certain expression systems, e.g. mammalian cells. Additionally, complete back-exchange of amide ${ }^{1} \mathrm{H}$ can require transient or chemically induced unfolding and refolding, which poses a particular challenge for proteins folded in the presence of suitable chaperons, or for solvent-protected sites of viral coat proteins [36] or integral membrane proteins [37, 38]. Inverse fractional deuteration (iFD) recently proposed by Medeiros-Silva and coworkers addresses this problem by expression in $\mathrm{H}_{2} \mathrm{O}$ and addition of ${ }^{2} \mathrm{H}$-glucose [39]. Despite a rather moderate level of incorporation of deuterium (10-40\%, inversely to the case of FD), remarkable resolution enhancement was observed at $60 \mathrm{kHz}$ MAS for ubiquitin and the ion channel KcsA. Most importantly, iFD provided access to backbone and side-chain resonances in transmembrane regions of KcsA.

Fully protonated samples are by far the easiest and least expensive to obtain. The potential of side-chain resonances for structure determination was recognized by the groups of Rienstra [40], Pintacuda [41] and Linser [42], however, detailed studies were hampered by limited resolution in ${ }^{1} \mathrm{H}$ side-chains at $40-60 \mathrm{kHz}$ MAS. Recent development of probes capable of rotor spinning up to $111 \mathrm{kHz}$ has dramatically improved ${ }^{1} \mathrm{H}$ resolution in fully protonated natural abundance materials and isotopically enriched biosolids [34, 43-45]. We have recently demonstrated that this new MAS condition increases the ${ }^{1} \mathrm{H}$ resolution for general application to challenging targets, in particular for atomic level structure determination of relatively large proteins $[36,46]$.

In this context, a series of questions become pertinent: at the magnetic field and MAS rates available today, is the highest resolution still enabled by deuteration? What is the effect of proton dilution at the highest MAS, and which labeling schemes optimize information available from backbone and side-chains? In the following, we address these questions by presenting ${ }^{1} \mathrm{H}$-detected ${ }^{15} \mathrm{~N}$ - and ${ }^{13} \mathrm{C}$-CP-HSQC spectra for three labeling schemes yielding different levels of proton content, and we critically compare the benefits of $111 \mathrm{kHz}$ and $1 \mathrm{GHz}$ magnetic field in terms of resolution and coherence lifetimes on two microcrystalline samples.

\section{Results and Discussion}

The microcrystalline protein GB1 was used as a model system to quantify the impact of deuteration on proton resolution in ${ }^{1} \mathrm{H}$-detected solid-state NMR spectra. Three uniformly- 
$\left[{ }^{13} \mathrm{C},{ }^{15} \mathrm{~N}\right]$-labelled samples containing different amounts of protons were prepared: 1) a perdeuterated protein expressed in $\mathrm{D}_{2} \mathrm{O}$ growth medium with deuterated glucose, with exchangeable amide ${ }^{1} \mathrm{H}$ reintroduced from protonated buffer during the purification $\left({ }^{D} \mathrm{~GB} 1\right)$; 2) a protein partially deuterated in side-chains expressed in $\mathrm{H}_{2} \mathrm{O}$ using deuterated glucose, a. k. a. inverse fractionally deuterated [39] ( $\left.{ }^{\mathrm{F} D} \mathrm{~GB} 1\right)$ and 3) a fully protonated protein expressed in $\mathrm{H}_{2} \mathrm{O}$ with protonated glucose $\left({ }^{\mathrm{H}} \mathrm{GB} 1\right)$.

All samples were purified and crystallized according to the same protocol (see Materials and Methods), and packed into $0.7 \mathrm{~mm}$ rotors. To ensure consistent results, all NMR experiments were performed using the same MAS probe and $B_{0}$ field $(25.4 \mathrm{~T})$, at the same temperature, and with $B_{0}$ homogeneity monitored before every measurement. Three 2D fingerprint cross-polarization HSQC (CP-HSQC) spectra were acquired with extensive sampling in the indirect dimension for each sample: ${ }^{15} \mathrm{~N},{ }^{1} \mathrm{H}-\mathrm{CP}-\mathrm{HSQC}$, aliphatic and aromatic ${ }^{13} \mathrm{C},{ }^{1} \mathrm{H}$-CP-HSQC. Fingerprint spectra were checked to ensure that only crystal form $\mathrm{A}$ of GB1 is present [47], and crystal quality was monitored on ${ }^{15} \mathrm{~N}$ linewidths. A limited variability of ${ }^{15} \mathrm{~N}$ shifts is observed for specific exposed residues in all preparations, which is inherent to instantaneous crystallization methods. Measurements were performed at 111 and $60 \mathrm{kHz}$ MAS, thus representing the highest MAS rate available in a commercial probe $(0.7 \mathrm{~mm})$ and experimental conditions characteristic of the previous generation probes $(1.3 \mathrm{~mm})$.

Figure 1 shows a comparison of the ${ }^{15} \mathrm{~N}-\mathrm{CP}-\mathrm{HSQC}$ spectra for the three samples and the two MAS conditions, and the representative ${ }^{1} \mathrm{H}$ cross-sections and linewidths for all resolved peaks are reported in Figure 2. The best amide ${ }^{1} \mathrm{H}$ resolution of approximately $80 \mathrm{~Hz}$ is achieved for ${ }^{\mathrm{D}} \mathrm{GB} 1$ at $111 \mathrm{kHz}$ (Fig. 2d), and is nearly as good at $60 \mathrm{kHz}$ MAS (Fig. 2c). The resolution limit is highly specific to the sample conditions, including the target protein itself, and determined primarily by intrinsic heterogeneity (local static disorder) and, to a smaller extent, by $B_{0}$ field inhomogeneity. In this respect, GB1 spectral resolution is inferior to proteins such as chicken $\alpha$-spectrin $\mathrm{SH} 3$ domain (best ${ }^{1} \mathrm{H}^{\mathrm{N}}$ linewidths of $39 \pm 10 \mathrm{~Hz}$ at $23.5 \mathrm{~T}$ and $60 \mathrm{kHz}$ MAS [15] or $19 \pm 3 \mathrm{~Hz}$ at $9.4 \mathrm{~T}$ and $24 \mathrm{kHz}$ MAS [11] reported for samples in 1:9 $\mathrm{H}_{2} \mathrm{O}: \mathrm{D}_{2} \mathrm{O}$ buffer) or ubiquitin $(41 \pm 12 \mathrm{~Hz}$ at $20.0 \mathrm{~T}$ and $100 \mathrm{kHz}$ MAS for a sample in $100 \%$ $\mathrm{H}_{2} \mathrm{O}$ [18]) which form more ideal microcrystals. On the other hand, this larger heterogeneity brings GB1 somewhat closer to samples of particular interest of ssNMR such as protein assemblies, membrane-embedded proteins, or amyloid fibrils.

At $60 \mathrm{kHz}$ MAS, full protonation $\left({ }^{\mathrm{H}} \mathrm{GB} 1\right)$ results in severe ${ }^{1} \mathrm{H}$ line broadening as the ${ }^{1} \mathrm{H}^{\mathrm{N}}$ median linewidth is $247 \mathrm{~Hz}$. In this spinning condition, iFD indeed represents an efficient strategy to lower the proton linewidth [39]. Here we observe a reduction of approx. $25 \%$ with respect to ${ }^{\mathrm{H}} \mathrm{GB} 1$, with a median linewidth of $187 \mathrm{~Hz}$.

The situation is dramatically changed with increased MAS rates. The effect of changing MAS rates from 60 to $111 \mathrm{kHz}$ is a $44 \%$ and $53 \%$ reduction of ${ }^{1} \mathrm{H}^{\mathrm{N}}$ linewidth for ${ }^{\mathrm{iFD}} \mathrm{GB} 1$ and ${ }^{\mathrm{H}} \mathrm{GB} 1$, respectively, while the ${ }^{1} \mathrm{H}$ linewidth is only marginally different in ${ }^{\mathrm{D}} \mathrm{GB} 1$. As a result, the impact of partial deuteration is far less pronounced at $111 \mathrm{kHz}$, and the ${ }^{15} \mathrm{~N}-\mathrm{CP}-\mathrm{HSQC}$ spectra of ${ }^{\mathrm{i} D \mathrm{D}} \mathrm{GB} 1$ and ${ }^{\mathrm{H}} \mathrm{GB} 1$ can hardly be distinguished (Fig. 1e,f). We estimate the overall linewidth improvement to be only $10 \%$ w.r.t. a fully protonated sample.

While only signals from amide ${ }^{1} \mathrm{H}$ can be acquired from ${ }^{\mathrm{D}} \mathrm{GB} 1$, the two samples expressed in $\mathrm{H}_{2} \mathrm{O}$ show full protonation at alpha positions, which can be monitored with ${ }^{13} \mathrm{C}-\mathrm{CP}-\mathrm{HSQC}$. The excellent resolution of the $\alpha$-region of the ${ }^{13} \mathrm{C},{ }^{1} \mathrm{H}-\mathrm{CP} \mathrm{HSQC}$ enabled quantification of ${ }^{1} \mathrm{H} \alpha$ linewidths for 60 and $111 \mathrm{kHz}$ MAS. As can be appreciated from spectra in Figure 3a-d and from representative cross-sections in Figure 4a-b, iFD considerably improves resolution at $60 \mathrm{kHz}$ MAS (by approx. 25\%). However, similarly to amide ${ }^{1} \mathrm{H}$, narrower linewidths are obtained by faster spinning than by partial proton dilution. At $111 \mathrm{kHz}$, iFD undoubtedly reduces observed linewidths for all resolved resonances, but rarely more than by $20 \%$.

Coherence lifetimes measured for ${ }^{1} \mathrm{H}$ at 60 and $111 \mathrm{kHz}$ MAS provide a deeper insight into observed linewidths (Fig. 5). Most strikingly, ${ }^{1} \mathrm{H}^{\mathrm{N}} \mathrm{T}_{2}$ ' increases steeply with MAS rate in this spinning regime regardless of the labeling scheme, halving the coherent contribution to the linewidths.

In the case of ${ }^{D} \mathrm{~GB} 1,{ }^{1} \mathrm{H}^{\mathrm{N}}$ coherence lifetimes of $23 \mathrm{~ms}$ were obtained at $111 \mathrm{kHz}$ MAS. In the past literature, such long ${ }^{1} \mathrm{H}^{\mathrm{N}}$ lifetimes were only reported at slower MAS rates thanks to 


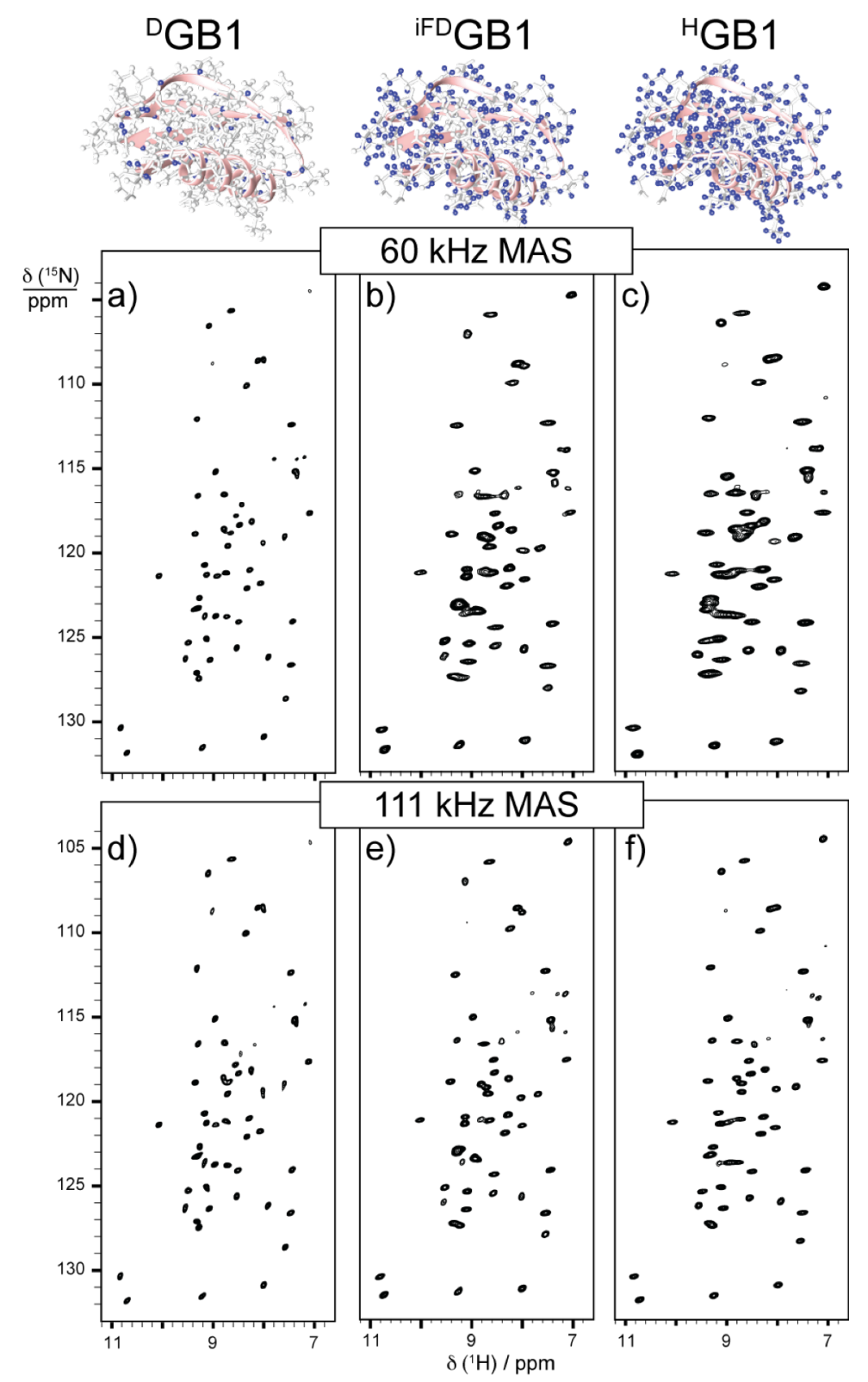

Fig. 1. ${ }^{15} \mathrm{~N}-\mathrm{CP}-\mathrm{HSQC}$ of ${ }^{\mathrm{D}} \mathrm{GB} 1(\mathrm{a}, \mathrm{d}),{ }^{\mathrm{iFD}} \mathrm{GB} 1(\mathrm{~b}, \mathrm{e})$ and ${ }^{\mathrm{H}} \mathrm{GB} 1$ (c,f) recorded on a $1 \mathrm{GHz}$ NMR spectrometer with $60 \mathrm{kHz}(\mathrm{a}, \mathrm{b}, \mathrm{c})$ and $111 \mathrm{kHz}$ MAS (d,e,f). In order to faithfully reproduce the linewidths in 2D contour plots, the lowest contour was normalized for each spectrum with respect to an average intensity of five resolved peaks (N8, T11, A26, D40, W43). The ratio of contour levels was set to 1.2 .

extremely high proton dilution by perdeuteration and sparse reprotonation of exchangeable sites in $\mathrm{D}_{2} \mathrm{O} / \mathrm{H}_{2} \mathrm{O}$ mixtures $[9,11,15]$. The improvement in coherence lifetimes due to increased MAS frequency corresponds to a decrease of the ${ }^{1} \mathrm{H}^{\mathrm{N}}$ homogenous linewidth from 25 to $14 \mathrm{~Hz}$ (cf. Table 1), which is small compared with inhomogeneous contributions to the line, and accounts for a very minor resolution gain as observed in the ${ }^{15} \mathrm{~N}-\mathrm{CP}-\mathrm{HSQC}$ spectra in Figure 1a,d.

In the case of the samples with higher proton content, ${ }^{1} \mathrm{H}^{\mathrm{N}} \mathrm{T}_{2}$ ' are significantly shorter. At both spinning rates, inverse fractional deuteration increases ${ }^{1} \mathrm{H}^{\mathrm{N}}$ coherence lifetime by about $40 \%$ compared to full protonation. Comparing 111 with $60 \mathrm{kHz}$ MAS, the improvement in ${ }^{1} \mathrm{H}^{\mathrm{N}}$ $\mathrm{T}_{2}$ ' corresponds to a decrease of the ${ }^{1} \mathrm{H}^{\mathrm{N}}$ homogenous linewidth from 132 to $46 \mathrm{~Hz}$, and from 182 to $59 \mathrm{~Hz}$, for ${ }^{\mathrm{i} F \mathrm{~GB}} 1$ and ${ }^{\mathrm{H}} \mathrm{GB} 1$, respectively. These values represent a substantial 
a)
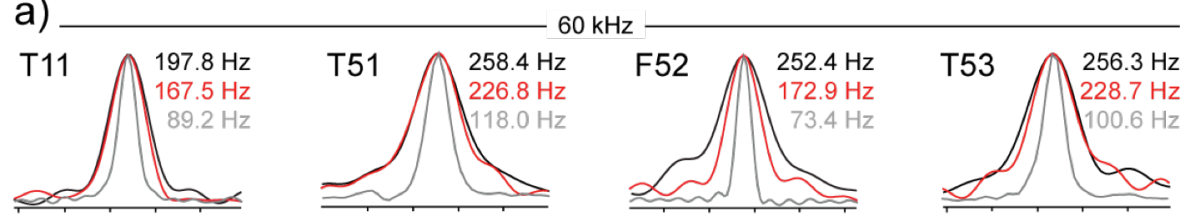

b)
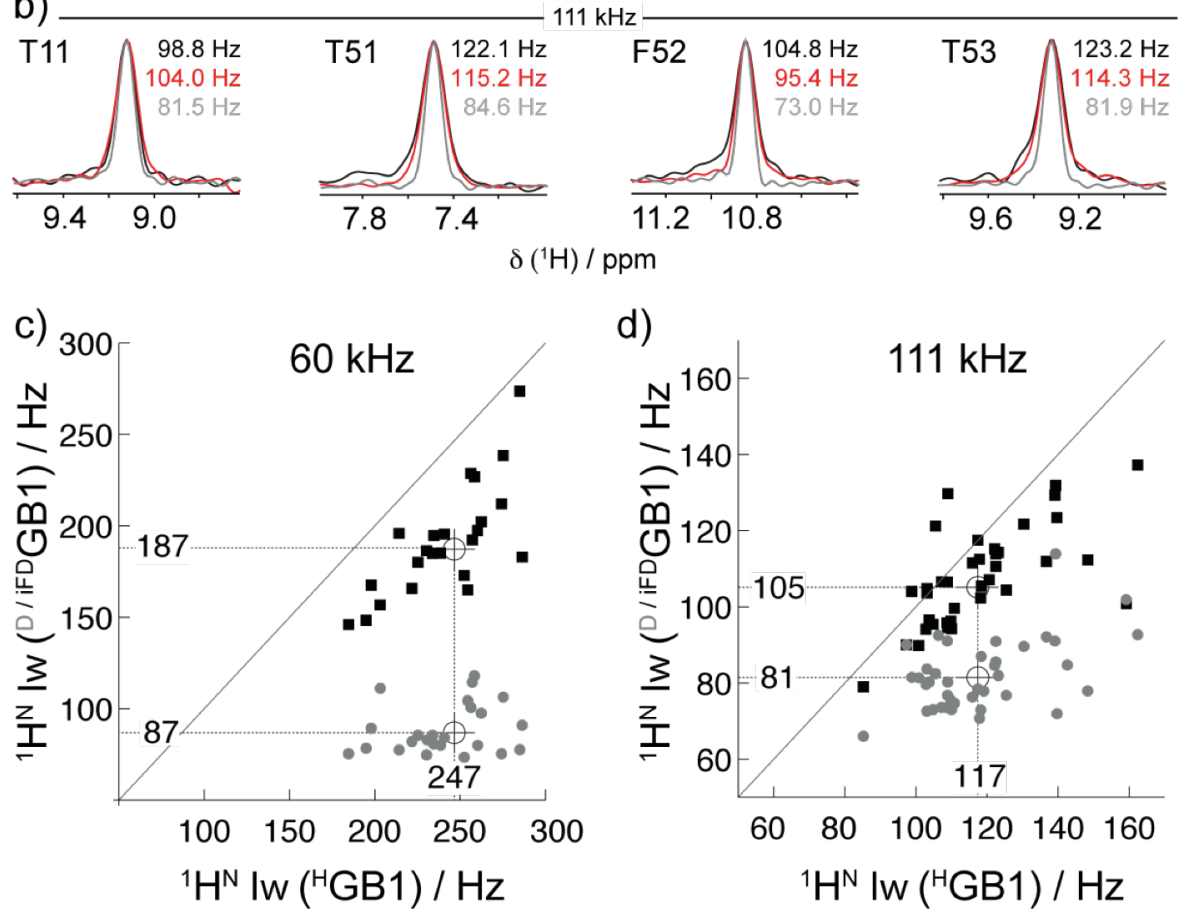

Fig. 2. ${ }^{1} \mathrm{H}$ cross-sections from the ${ }^{15} \mathrm{~N}-\mathrm{CP}-\mathrm{HSQC}$ of ${ }^{\mathrm{D}} \mathrm{GB} 1$ (grey), ${ }^{\mathrm{iFD}} \mathrm{GB} 1$ (red) and ${ }^{\mathrm{H}} \mathrm{GB} 1$ (black), recorded with $60 \mathrm{kHz}$ (a) and $111 \mathrm{kHz}$ (b) MAS on a $1 \mathrm{GHz}$ spectrometer, normalized w.r.t. peak intensity. Correlations between ${ }^{1} \mathrm{H}$ linewidths observed for resolved cross-signals in either ${ }^{\mathrm{D}} \mathrm{GB} 1$ (grey circles) or ${ }^{\mathrm{F} D} \mathrm{~GB} 1$ (black squares) and ${ }^{\mathrm{H}} \mathrm{GB} 1$, at $60 \mathrm{kHz}$ (c) and $111 \mathrm{kHz}$ (d) MAS. The median of obtained values is shown by a crossed circle in each plot.

portion of the observed linewidths, indicating more balanced homogeneous and inhomogeneous contributions. Median linewidths of amide and $\alpha$-protons and their approximate homoneneous and inhomogenous contributions are summarized in Table 1. Contrary to ${ }^{1} \mathrm{H}$ linewidths, the feasibility of recording INEPT-HSQC spectra is determined solely by the ${ }^{1} \mathrm{H}$ coherence lifetime. Such spectra are of particular interest for example for samples with extended flexible regions [48], but yet inaccessible without extensive deuteration. In Figure 6 we compare the relative efficiency of dipolar- and scalar-based ${ }^{15} \mathrm{~N}$ ${ }^{1} \mathrm{H}$ correlation spectra for the three GB1 samples discussed above. Thanks to the long ${ }^{1} \mathrm{H}^{\mathrm{N}}$ coherence lifetime at $111 \mathrm{kHz}$ MAS, the integral signal in the INEPT-HSQC is $76 \%$ w.r.t. the CP-HSQC for ${ }^{\mathrm{D}} \mathrm{GB} 1$. In ${ }^{\mathrm{iFD}} \mathrm{GB} 1$ and ${ }^{\mathrm{H}} \mathrm{GB} 1$, however, the respective ratio is about $25-30 \%$. In these conditions it is feasible to acquire a complete 2D correlation within 1 hour (Fig. $6 \mathrm{~d}, \mathrm{e}$ ), however, significantly longer acquisition is required for samples with less intrinsic sensitivity or shorter ${ }^{1} \mathrm{H}$ coherence lifetime. Further benefits in resolution and sensitivity of scalar-based correlations are therefore anticipated with the advent of a new generation of probes with capability for faster MAS.

Coherence lifetimes were also measured for ${ }^{15} \mathrm{~N},{ }^{13} \mathrm{C} \alpha$ and ${ }^{13} \mathrm{C}^{\prime}$ under low power ${ }^{1} \mathrm{H}$ decoupling and summarized in Figure 5. Due to proximity to proton(s), ${ }^{13} \mathrm{C} \alpha$ and ${ }^{15} \mathrm{~N}$ show the largest $\mathrm{T}_{2}$ ' enhancement $(>100 \%)$ when MAS rate is increased from 60 to $111 \mathrm{kHz}$ for all samples, and smaller but relevant gains (up to $80 \%$ ) are observed for ${ }^{13} \mathrm{C}^{\prime}$ (except for ${ }^{\mathrm{D}} \mathrm{GB} 1$ ). Longer $\mathrm{T}_{2}$ ' are connected to higher efficiencies of scalar-based ${ }^{13} \mathrm{C}-{ }^{13} \mathrm{C}$ coherence transfers, 

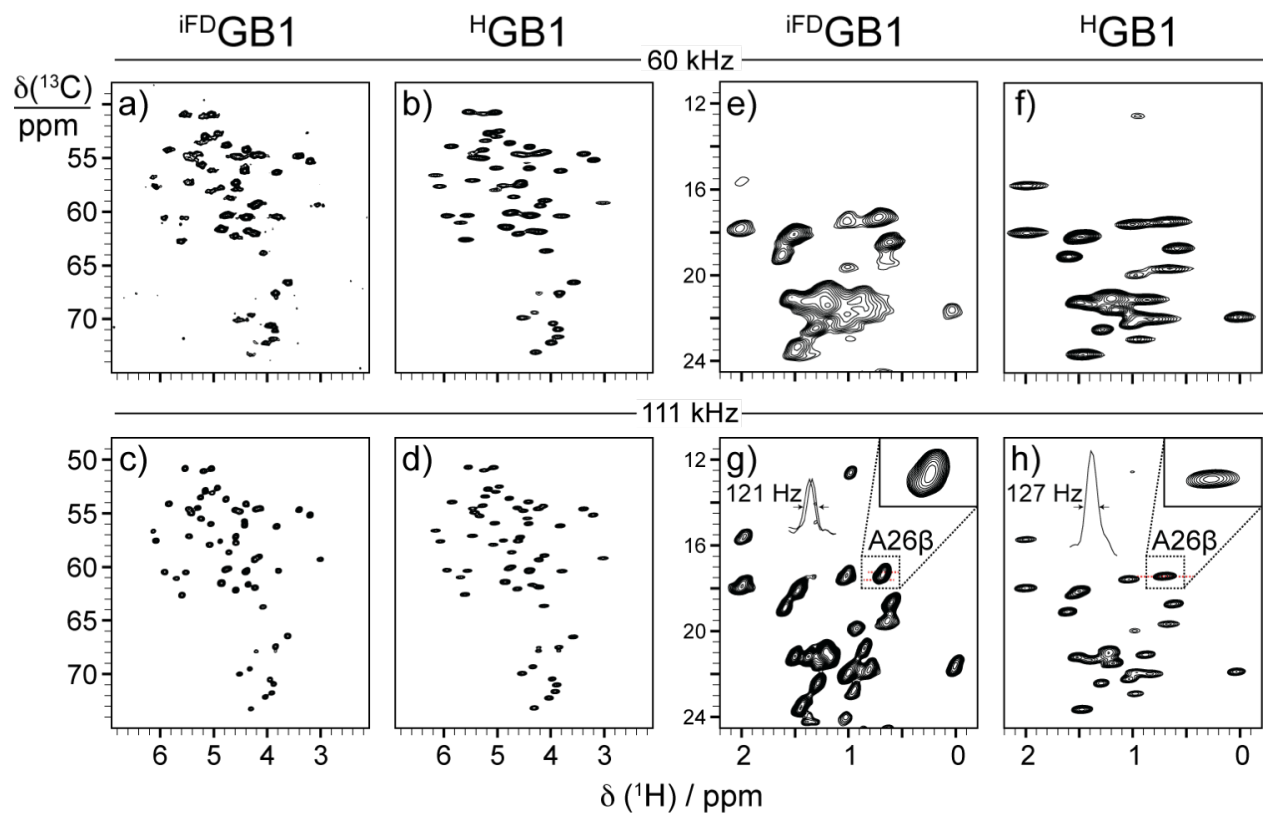

Fig. 3. Ha-Ca (a-d) and methyl regions (e-h) of ${ }^{13} \mathrm{C}-\mathrm{CP}-\mathrm{HSQC}$ of ${ }^{\mathrm{iFD}} \mathrm{GB} 1(\mathrm{a}, \mathrm{c}, \mathrm{e}, \mathrm{g})$ and ${ }^{\mathrm{H}} \mathrm{GB} 1$ (b,d,f,h) recorded on a $1 \mathrm{GHz}$ spectrometer with $60 \mathrm{kHz}(\mathrm{a}, \mathrm{b}, \mathrm{e}, \mathrm{f})$ and $111 \mathrm{kHz}(\mathrm{c}, \mathrm{d}, \mathrm{g}, \mathrm{h}) \mathrm{MAS}$. Representative ${ }^{1} \mathrm{H}$ cross-sections and linewidths are reported for the $\mathrm{C} \beta-\mathrm{H} \beta$ correlation of Ala26 (g,h). In order to faithfully reproduce the linewidths in 2D contour plots, the lowest contour was normalized for each spectrum with respect to an average intensity of five resolved peaks (E15, T17, V21, V29, T51). The ratio of contour levels was set to 1.2 .

which are essential building blocks of triple-resonance experiments. The sensitivity of experiments such as $(\mathrm{H})(\mathrm{CA}) \mathrm{CB}(\mathrm{CA}) \mathrm{NH}$ or $(\mathrm{H})(\mathrm{CO}) \mathrm{CA}(\mathrm{CO}) \mathrm{NH}[49]$ is therefore enhanced at faster MAS.

It is worth noting that inverse fractional deuteration extends all heteronuclear $\mathrm{T}_{2}$ ' by approximately $50 \%$ w.r.t. full protonation. Despite this, full protonation at faster MAS yields higher ${ }^{13} \mathrm{C}$ resolution. In fact, inverse fractional deuteration entails random incorporation of deuterons in the side-chains, inevitably leading to mixtures of isotopomers. As a consequence of the ${ }^{2} \mathrm{H}$-induced ${ }^{13} \mathrm{C}$ isotope shift and additional ${ }^{1} \mathrm{~J}_{\mathrm{CD}}$ couplings, side-chain ${ }^{13} \mathrm{C}$ resolution is deteriorated for a number of specific residues in ${ }^{\mathrm{F} D} \mathrm{~GB} 1$. As shown in Figure $3 e-$ $\mathrm{h}$, this adverse effect is pronounced for methyl groups of alanines, valines, leucines and $\gamma_{2^{-}}$ site of isoleucines, where the populations of isotopomers are similar $\left(\mathrm{CH}_{3}: \mathrm{CH}_{2} \mathrm{D}: \mathrm{CHD}_{2}\right.$ ratio is $1: 3: 3$, assuming $50 \%$ random deuteration). Interestingly, for ${ }^{\mathrm{iFD}} \mathrm{GB} 1$ methyl signals also exhibit a non-negligible ${ }^{2} \mathrm{H}$-induced ${ }^{1} \mathrm{H}$ isotope shift, which confers a skewed appearance to the $2 \mathrm{D}$ lineshapes, and overall offsets any resolution advantage associated to the ${ }^{1} \mathrm{H}$ dilution. In contrast, for these signals fast MAS on a fully protonated sample combines full ${ }^{1} \mathrm{H}$ occupancy with optimal ${ }^{13} \mathrm{C}$ resolution. In the case of ${ }^{13} \mathrm{C} \alpha-\mathrm{H} \alpha$ correlations for ${ }^{\mathrm{F} D \mathrm{D}} \mathrm{GB} 1$, we do not observe any loss of sensitivity since $\alpha$-protons are recruited from the protonated solvent (less than $5 \%$ of ${ }^{1} \mathrm{H} \alpha$ dilution as quantified by Medeiros-Silva [39]), and linewidths are slightly improved compared to ${ }^{\mathrm{H}} \mathrm{GB} 1$. In contrast, a significant deuteration level for most methyl and certain methylene groups (up to $50 \%$ ), combined with adverse isotope effects, overall leads to a substantial loss of sensitivity w.r.t. a fully protonated sample at $111 \mathrm{kHz}$ MAS. Unfortunately, a reliable quantification of $\mathrm{S} / \mathrm{N}$ ratio of resonances in ${ }^{13} \mathrm{C}-{ }^{1} \mathrm{H}$ correlation spectra is impeded by variability of the actual amount of protein in $0.7 \mathrm{~mm}$ rotors. 

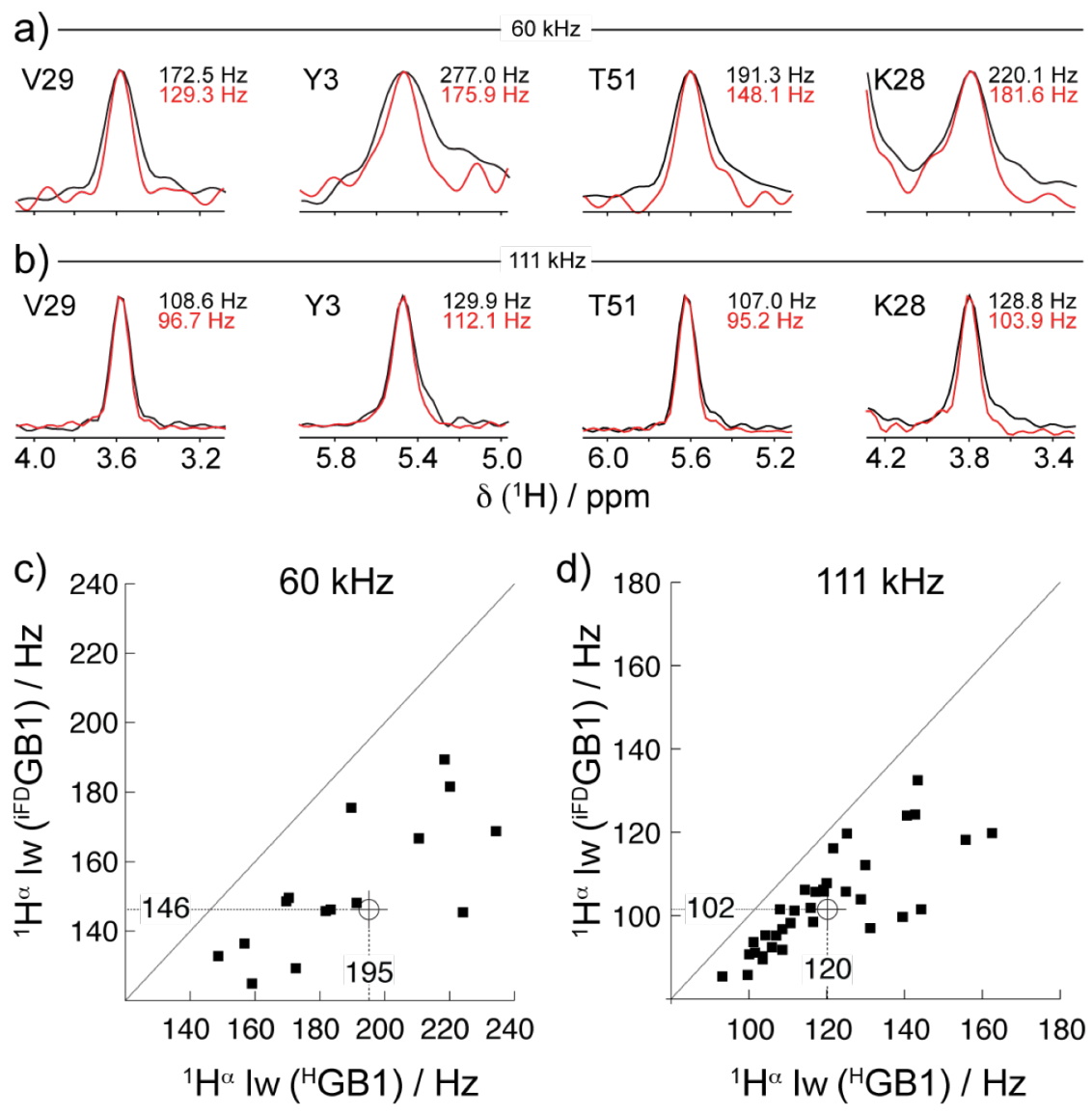

Fig. 4. ${ }^{1} \mathrm{Ha}$ cross-sections extracted from the ${ }^{13} \mathrm{C}-\mathrm{CP}-\mathrm{HSQC}$ of ${ }^{\mathrm{i} D \mathrm{G}} \mathrm{GB} 1$ (red) and ${ }^{\mathrm{H}} \mathrm{GB} 1$ (black) recorded on a $1 \mathrm{GHz}$ spectrometer with MAS rates of $60 \mathrm{kHz}$ (a) and $111 \mathrm{kHz}$ (b), normalized w.r.t. peak intensity. Correlations between ${ }^{1} \mathrm{Ha}$ linewidths observed for resolved cross-signals in ${ }^{\mathrm{i} D \mathrm{D}} \mathrm{GB} 1$ and ${ }^{\mathrm{H}} \mathrm{GB} 1$, at MAS rates of $60 \mathrm{kHz}$ (c) and $111 \mathrm{kHz}$ (d). The median of the values of each plot is denoted by a crossed circle.

Aromatic ${ }^{1} \mathrm{H}$ side-chain resonances are relevant yet under-explored NMR probes in solidstate NMR. Here fast MAS delivers aromatic ${ }^{13} \mathrm{C}-\mathrm{CP}-\mathrm{HSQC}$ fingerprints with unprecedented quality (Fig. 7). As shown for ${ }^{\mathrm{H}} \mathrm{GB} 1$, signals from all aromatic residues (1 Tryptophane, 3 Tyrosine and 2 Phenylalanine) are detectable with ${ }^{1} \mathrm{H}$ linewidths varying from 105 to $185 \mathrm{~Hz}$. Notably, the spectral pattern of ${ }^{\mathrm{F} D} \mathrm{~GB} 1$ is affected by uneven incorporation of deuterons into aromatic rings (Fig. 7a). Specifically, the $\mathrm{H} \xi_{3}$ resonance of Trp vanishes upon iFD and intensity of $H \delta_{1}$ is significantly reduced. In contrast, the intensities of $H \varepsilon_{3}, H \varepsilon_{2}$ and $H \xi_{2}$ remain largely unaffected, although $\mathrm{H}_{\varepsilon_{3}}$ experiences almost $30 \%$ decrease in ${ }^{1} \mathrm{H}$ linewidth, as expected from deuteration at $\mathrm{H} \xi_{3}$ position. Tyr $\mathrm{H} \varepsilon$ are present with full intensity in ${ }^{\mathrm{i} D} \mathrm{~GB} 1$, while significant ${ }^{1} \mathrm{H}$-dilution is observed for $\delta$-protons. Finally, population of all protons in Phe rings is greatly decreased, the effect being difficult to quantify due to signal overlap between $\delta, \varepsilon$ and $\zeta$ protons. Overall, the dilution of aromatic protons improves ${ }^{1} \mathrm{H}$ linewidths for some aromatic and proximal aliphatic protons, but at the same time it removes structurally relevant NMR probes. 
Table 1. Summary of linewidths for amide and $\alpha$-protons for different preparations of GB1 and AP205.

\begin{tabular}{|c|c|c|c|c|}
\hline Sample & $\begin{array}{c}\text { MAS rate } \\
(\mathrm{kHz})\end{array}$ & $\begin{array}{c}{ }^{1} \mathrm{H}^{\mathrm{N}}{ }^{\mathrm{lw}} \mathrm{exp}^{a} \\
(\mathrm{~Hz})\end{array}$ & $\begin{array}{c}{ }^{1} \mathrm{H}^{\mathrm{N}} \mathrm{Iw}_{\mathrm{hom}}{ }^{b} / \mathrm{Iw}_{\mathrm{inh}}{ }^{c} \\
(\mathrm{~Hz})\end{array}$ & $\begin{array}{c}{ }^{1} \mathrm{H}^{\alpha}{ } \mathrm{IW}_{\exp }{ }^{a} \\
(\mathrm{~Hz})\end{array}$ \\
\hline \multirow[t]{2}{*}{${ }^{\mathrm{H}} \mathrm{GB} 1$} & 60 & $247 \pm 34$ & $182 / 73$ & $195 \pm 47$ \\
\hline & 111 & $117 \pm 21$ & 59 / 73 & $120 \pm 21$ \\
\hline \multirow[t]{2}{*}{${ }^{\mathrm{iFD}} \mathrm{GB} 1$} & 60 & $187 \pm 32$ & $132 / 73$ & $146 \pm 19$ \\
\hline & 111 & $105 \pm 14$ & $46 / 73$ & $102 \pm 12$ \\
\hline \multirow[t]{2}{*}{${ }^{\mathrm{D}} \mathrm{GB} 1$} & 60 & $87 \pm 14$ & $25 / 73$ & $\mathrm{n} / \mathrm{a}$ \\
\hline & 111 & $81 \pm 13$ & $14^{d} / 73$ & $\mathrm{n} / \mathrm{a}$ \\
\hline${ }^{\mathrm{H}} \mathrm{AP} 205$ & 111 & $139 \pm 31$ & $106^{d} /-^{e}$ & $119 \pm 31$ \\
\hline${ }^{\mathrm{iFD}} \mathrm{AP} 205$ & 111 & $112 \pm 17$ & $96^{d} /-^{e}$ & $99 \pm 30$ \\
\hline
\end{tabular}

${ }^{a}$ median and standard deviation of residue-specific linewidths (FWHH)

${ }^{b}$ median of homogeneous contribution to linewidth estimated for each residue. In absence of residue-specific $\mathrm{T}_{2}$ ' data, we assumed a Voigt line shape with effective linewidth (IW $\left.\mathrm{wxp}_{\mathrm{e}}\right)$ dependent on Lorentzian homogeneous broadening ( $\left.\mathrm{I} \mathrm{W}_{\mathrm{hom}}\right)$ and Gaussian inhomogeneous broadening ( $\left.\mathrm{I} \mathrm{W}_{\text {inh }}\right)$ according to the approximate formula: $\mathrm{IW}_{\mathrm{exp}}=0.5346 \mathrm{I} \mathrm{W}_{\mathrm{hom}}+\left(0.2166 \mathrm{IW}_{\mathrm{hom}}{ }^{2}+\mathrm{IW}_{\mathrm{inh}}{ }^{2}\right)^{1 / 2}$

$c$ median of inhomogeneous contribution to linewidth. It was assumed that inhomogeneity was uniform between samples, and $I \mathrm{w}_{\text {inh }}$ equal to value for the respective residue in ${ }^{\mathrm{D}} \mathrm{GB} 1$ at $111 \mathrm{kHz} \mathrm{MAS}$

${ }^{d}$ homogeneous contribution estimated from the bulk $T_{2}$ ' measurement as $1 /\left(\pi T_{2}{ }^{\prime}\right)$, and assumed equal for all residues in ${ }^{\mathrm{D}} \mathrm{GB} 1$

${ }^{e}$ contributions to linewidths not evaluated in absence of reference data for deuterated AP205 sample

It is noteworthy that the overall benefit of inverse fractional deuteration depends on the amino acid composition of a protein. Figure 8 shows an approximate level of deuteration at particular positions of aliphatic side-chains, based on analysis of amino acid synthetic pathways in bacteria as well as experimental data reported by Medeiros-Silva et al [39]. When expression is performed in $100 \% \mathrm{H}_{2} \mathrm{O}$, most deuterons present in ${ }^{2} \mathrm{H}$-enriched glucose are transferred to the solvent, and only specific positions of 8 amino acid types remain deuterated to more than $30 \%$. In particular, the primary sequence of GB1 is devoid of serines, the amino acid with the highest incorporation of deuterons. Therefore, to draw more general conclusions we prepared an iFD sample of Acinetobacter phage 205 coat protein (130 a.a.), assembled in $2.5 \mathrm{MDa}$ virus-like particles of 180 near-equivalent copies [50, 51]. The frequency of the 8 amino acids with high incorporation level of deuterons $(S, A, E, Q, P$, $\mathrm{V}, \mathrm{L}, \mathrm{I})$ for AP205 is considerably higher (55\% of the sequence) than for GB1 $(38 \%)$; in particular, serines comprise $10 \%$ of the AP205CP sequence. The fingerprint spectra were acquired under the same experimental conditions as used in a study of the fully protonated AP205CP [36]. The ${ }^{15} \mathrm{~N}-\mathrm{CP}-\mathrm{HSQC}$ and the $\alpha$-regions of the ${ }^{13} \mathrm{C}-\mathrm{CP}-\mathrm{HSQC}$ spectra are shown in Figure 9a-b. Considerably higher spectral overlap is seen than for GB1, thus only 12 and 18 well resolved and intense peaks in each spectrum were selected for reliable linewidth estimation. Representative ${ }^{1} \mathrm{H}$ cross-sections from these spectra for both ${ }^{\text {iFD } A P 205}$ and ${ }^{\mathrm{H}} \mathrm{AP} 205$ are shown in Figure $9 e-f$, and the entire linewidth statistics compared in Figure 9c-d. In the case of AP205, iFD provides statistically meaningful decrease of linewidths even at $100 \mathrm{kHz}$ MAS, with approximately the same relative effect on amide $(-19 \%)$ and alpha ($17 \%)$ protons. The benefits of iFD are thus more emphasized than for GB1, which could be explained by (i) higher deuteration content and (ii) an overall higher relative contribution of homogeneous broadening to the linewidths. For example, bulk ${ }^{1} \mathrm{H}^{\mathrm{N}}$ coherence lifetimes at $100 \mathrm{kHz}$ MAS are 3.3 and $3.0 \mathrm{~ms}$ for ${ }^{\mathrm{iFD}} \mathrm{AP} 205$ and ${ }^{\mathrm{H}} \mathrm{AP} 205$ samples, which corresponds to homogeneous linewidths of 96 and $106 \mathrm{~Hz}$, respectively. These linewidths are significantly larger than for GB1, and are likely to be more representative of samples that are intrinsically more flexible or non-crystalline [46]. Coherent effects thus still determine the ${ }^{1} \mathrm{H}$ resolution at $100 \mathrm{kHz}$ MAS of either the fully protonated or iFD sample, and further linewidth reduction is envisaged with faster MAS. 


\section{Conclusions}

We showed that the increase of MAS rates from 60 to $100 \mathrm{kHz}$ (or $111 \mathrm{kHz}$ ) at ultra-high field provides a significantly higher improvement in resolution for ${ }^{1} \mathrm{H}$ resonances than what could be achieved by fractional deuteration. Both approaches may be jointly applied to improve resolution of amide or $\alpha$-protons, however, linewidths are still inferior to the case of perdeuteration with $100 \%$ amide ${ }^{1} \mathrm{H}^{\mathrm{N}}$ back-exchange. Even at $111 \mathrm{kHz} \mathrm{MAS}$, we observed a strong dependence of ${ }^{1} \mathrm{H}$ and heteronuclear coherence lifetimes on the deuteration level. For these two reasons, either highly or fractionally deuterated samples facilitate sequencespecific backbone resonance assignment. However, fully protonated proteins show higher resolution and sensitivity in aliphatic side-chains, and specifically for methyl resonances. Resolution benefits of the iFD labeling scheme seem to be quite dependent on the amino acid composition of a protein. We conclude that fully protonated samples represent a more general and versatile solution for studies at ultrafast MAS.

\section{Materials and Methods \\ Sample preparation}

Uniformly ${ }^{13} \mathrm{C},{ }^{15} \mathrm{~N}$-labeled GB1 and AP205 coat protein (AP205CP) samples were expressed in Escherichia coli, purified, and crystallized as described previously [36, 51-53]. To obtain samples with different proton/deuterium ratio, ${ }^{\mathrm{F} D \mathrm{D}} \mathrm{GB} 1$ and ${ }^{\mathrm{iFD}} \mathrm{AP} 205 \mathrm{CP}$ were expressed in $\mathrm{H}_{2} \mathrm{O}$-based medium containing $1.0 \mathrm{~g} / \mathrm{L}$ of ${ }^{15} \mathrm{NH}_{4} \mathrm{Cl}$ and $2 \mathrm{~g} / \mathrm{L}$ of deuterated ${ }^{13} \mathrm{C}$-glucose (d7) [39], while ${ }^{\mathrm{H}} \mathrm{GB} 1$ and ${ }^{\mathrm{H}} \mathrm{AP} 205 \mathrm{CP}$ were expressed using $\mathrm{H}_{2} \mathrm{O}$ and protonated ${ }^{13} \mathrm{C}$-glucose. ${ }^{\mathrm{D}} \mathrm{GB} 1$ was expressed using $\mathrm{D}_{2} \mathrm{O}-$ based medium containing ${ }^{15} \mathrm{NH}_{4} \mathrm{Cl}$ and deuterated ${ }^{13} \mathrm{C}$-glucose, lyophilized two times from $\mathrm{D}_{2} \mathrm{O}$ before addition in the medium. All the proteins were then extracted, purified and microcrystallized in $\mathrm{H}_{2} \mathrm{O}-$ based buffer according to the protocols described previously. Microcrystals were harvested and packed into $0.7 \mathrm{~mm}$ rotors by ultracentrifugation at $120,000 \times \mathrm{g}$ at $4^{\circ} \mathrm{C}$ for 1 hour using a $1.3 \mathrm{~mm}$ device purchased from Giotto Biotech [54, 55]. A $0.7 \mathrm{~mm}$ rotor was inserted into a $1.3 \mathrm{~mm}$ rotor and sealed with two fluorinated rubber plugs at the bottom side of the larger rotor. The packing protocol is under constant development and readers are encouraged to contact the authors for up-to-date advice.

\section{NMR spectroscopy and data processing}

All spectra were acquired on a $1 \mathrm{GHz}$ spectrometer and MAS rate of $60 \mathrm{kHz}$ (AP205CP and GB1), $100 \mathrm{kHz}$ (AP205CP) or $111 \mathrm{kHz}$ (GB1) using a Bruker $0.7 \mathrm{~mm}$ HCN probe. Sample temperature was
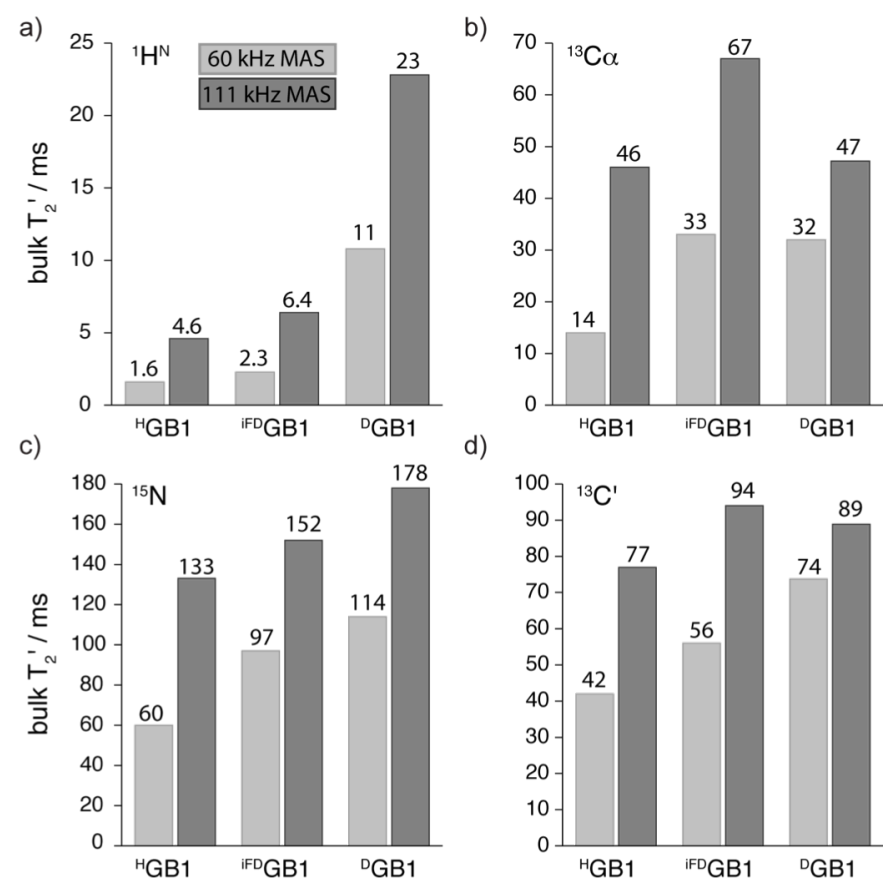

Fig. 5. Bulk transverse coherence lifetimes $\left(\mathrm{T}_{2}{ }^{\prime}\right)$ of ${ }^{1} \mathrm{H}^{\mathrm{N}}(\mathrm{a}),{ }^{13} \mathrm{C} \alpha(\mathrm{b}),{ }^{15} \mathrm{~N}(\mathrm{c})$ and ${ }^{13} \mathrm{C}^{\prime}(\mathrm{d})$ measured for GB1 samples on a $1 \mathrm{GHz}$ spectrometer at 60 (grey bars) and $111 \mathrm{kHz}$ (black bars) MAS under low power heteronuclear ${ }^{1} \mathrm{H}$ decoupling for ${ }^{13} \mathrm{C}$ and ${ }^{15} \mathrm{~N}$ (see Materials and Methods). 
maintained at about $10^{\circ} \mathrm{C}$ using a Bruker cooling unit with regulated $\mathrm{N}_{2}$ gas directed at the rotor. The temperature of this gas measured just before reaching the sample was 280,260 and $255 \mathrm{~K}$ at 60,100 and $111 \mathrm{kHz}$ MAS respectively. The rotor with ${ }^{\mathrm{iFD}} \mathrm{AP} 205$ was spun only to $100 \mathrm{kHz}$ without exceeding a limit of 5 bar drive pressure in the prototype $0.7 \mathrm{~mm}$ probe (note that since then the stator has been redesigned).

The dipolar-based ${ }^{15} \mathrm{~N}$ - and ${ }^{13} \mathrm{C}-\mathrm{HSQC}$ experiments follow, with little modifications, those introduced by Rienstra and co-workers $[40,56]$. For ${ }^{1} \mathrm{H}-{ }^{15} \mathrm{~N}$ and ${ }^{1} \mathrm{H}^{13} \mathrm{C} \mathrm{CP}$, we optimized around nutation frequencies of $5 / 4 \omega_{R}$ for ${ }^{1} \mathrm{H}$ and $1 / 4 \omega_{R}$ for heteronuclei $\left({ }^{15} \mathrm{~N}\right.$ or $\left.{ }^{13} \mathrm{C}\right)$, with a $10 \%$ linear ramp applied on the ${ }^{1} \mathrm{H}$ channel. Low-power WALTZ-16 proton decoupling of $10 \mathrm{kHz}$ was applied for heteronuclear decoupling for ${ }^{\mathrm{D}} \mathrm{GB} 1$ and ${ }^{\mathrm{i} F \mathrm{D}} \mathrm{GB} 1$ samples, whereas for ${ }^{\mathrm{H}} \mathrm{GB} 1$ low-power sITPPM of 15 and $27 \mathrm{kHz}$ was applied at 60 and $111 \mathrm{kHz}$ MAS, respectively [57]. The optimal decoupling scheme was chosen for each sample to obtain maximum ${ }^{15} \mathrm{~N} \mathrm{~T}_{2}$. Note that at $111 \mathrm{kHz}$ MAS sITPPM decoupling with $10-15 \mathrm{kHz}{ }^{1} \mathrm{H}$ RF may perform better than with $27 \mathrm{kHz}$ RF. Suppression of solvent signals [8] was achieved using the MISSISSIPPI scheme [58] applied for $200 \mathrm{~ms}$, and the interscan delay ranged from 0.8 to $1 \mathrm{~s}$ for GB1, and $1-1.4 \mathrm{~s}$ for AP205CP.

Concerning coherence lifetimes, ${ }^{15} \mathrm{~N}$ and ${ }^{1} \mathrm{H}$ bulk coherence lifetimes $\left(\mathrm{T}_{2}{ }^{\prime}\right)$ were measured using a ${ }^{15} \mathrm{~N}$-CP-HSQC pulse sequence with a variable-time echo period on the respective channel. For ${ }^{13} \mathrm{C}_{2}{ }_{2}$,
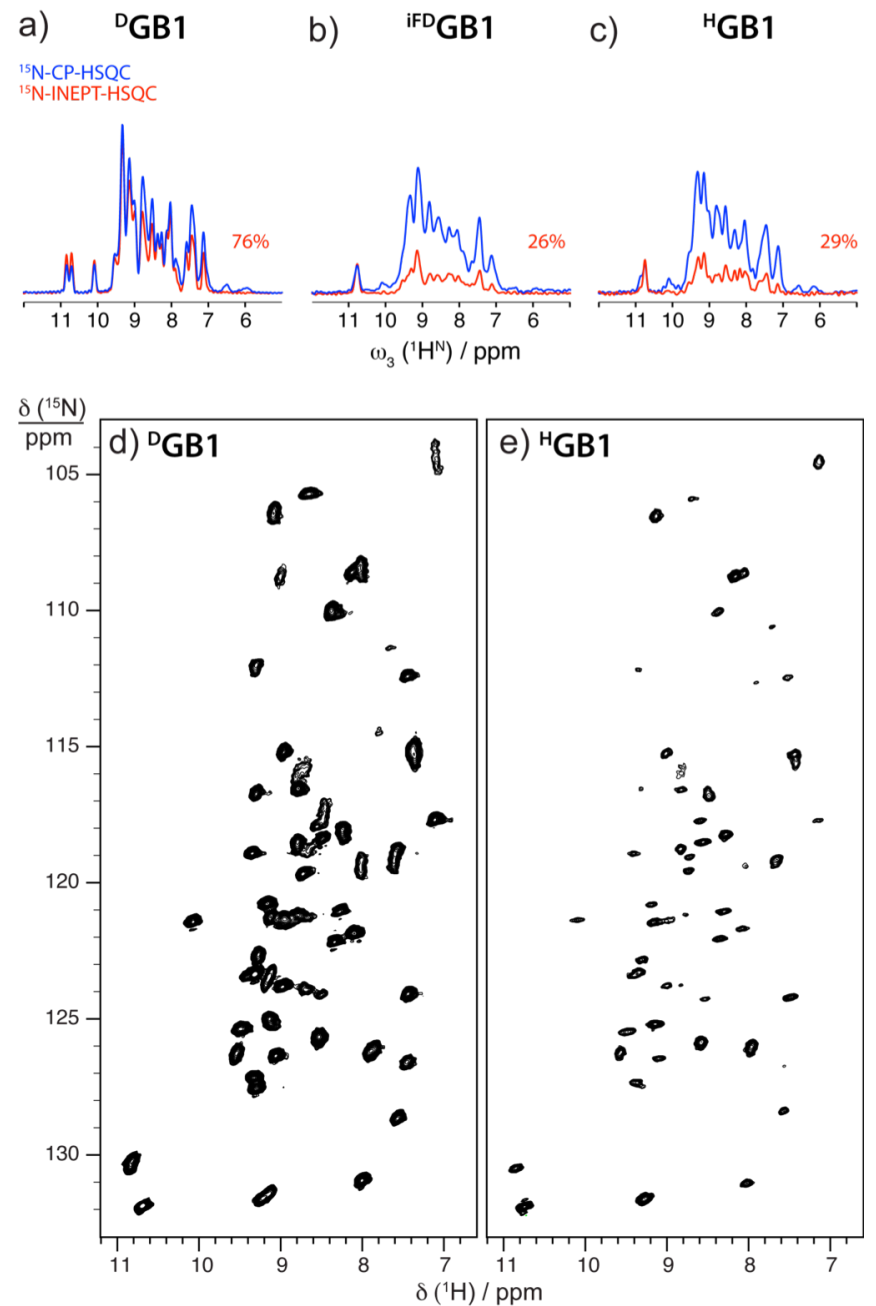

Fig. 6. Relative efficiency of dipolar- (in blue) and scalar-based (in red) HSQC shown on 1D firstFID spectra for ${ }^{D}$ GB1 (a), ${ }^{\text {FD }}$ GB1 (b) and ${ }^{H}$ GB1 (c). CP-HSQC spectra were normalized between samples to show equal integrals (a-c). Relative scale of CP- and INEPT-HSQC was preserved, and the ratio of their integrals is reported on every panel. $2 \mathrm{D}{ }^{15} \mathrm{~N}-I N E P T-H S Q C$ spectra for ${ }^{\mathrm{D}} \mathrm{GB} 1$ (d) and ${ }^{\mathrm{H}} \mathrm{GB} 1$ (e) acquired in the same experimental time of 1 hour at $111 \mathrm{kHz}$ MAS and at $1 \mathrm{GHz}$ spectrometer. To reflect the difference in sensitivity, spectra are plotted with the same contour scale with the lowest contour at 5 standard deviations of noise, and the ratio between contours of 1.2 . 


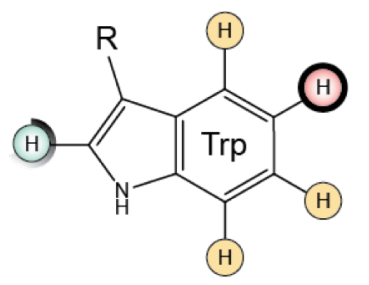

iFDGB1

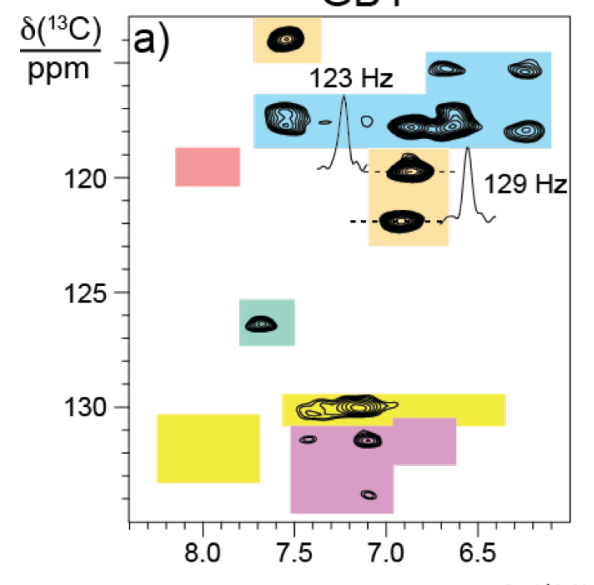<smiles>[R]c1c([O-])c([Hg])c(O)c([Hg])c1[O-]</smiles><smiles>[R]C1=C([O])C(=O)C([O])C(=O)C1=O</smiles>

${ }^{\mathrm{H}} \mathrm{GB} 1$

$$
\delta\left({ }^{1} \mathrm{H}\right) / \mathrm{ppm}
$$

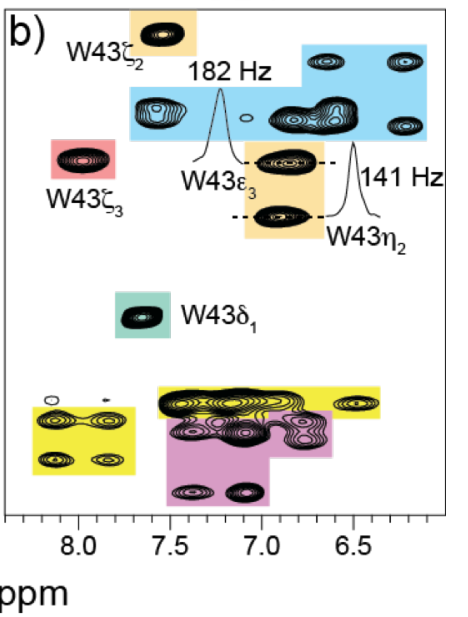

Fig. 7. Aromatic region of ${ }^{13} \mathrm{C}-\mathrm{CP}-\mathrm{HSQC}$ of ${ }^{\mathrm{iFD}} \mathrm{GB} 1$ (a) and ${ }^{\mathrm{H}} \mathrm{GB} 1$ (b) recorded on a $1 \mathrm{GHz}$ spectrometer with $111 \mathrm{kHz}$ MAS. ${ }^{1} \mathrm{H}$ cross-sections and linewidths are reported for two signals of Trp43. A color code illustrates the amino acid-specific assignments of tryptophan, tyrosine and phenylalanine protons, while a black ring of increasing angular width reports on the approximate extent of suppression of a signal by deuteration (no impact, no circle; deletion, bold black circle). In order to faithfully reproduce the linewidths in 2D contour plots, the lowest contour was normalized for each spectrum with respect to an average intensity of two resolved W43 peaks $\left(\zeta_{2}\right.$ and $\eta_{2}$ ). The ratio of contour levels was set to 1.2.

we employed a carbon-detected CP sequence with a selective refocusing pulse. ReBURP [59] pulses of duration of $680 \mathrm{~ms}$ and $1300 \mathrm{~ms}$ were applied for ${ }^{13} \mathrm{C}^{\prime}$ and ${ }^{13} \mathrm{C} \alpha$, at the ${ }^{13} \mathrm{C}$ carrier offsets of 176 and $58 \mathrm{ppm}$, respectively.

Spectra were apodized in the indirect dimension with $60^{\circ}$ shifted square sine-bells (« qsine $3 »$ in Bruker Topspin), and zero-filled to at least four times the number of points in all dimensions. No apodization was applied in ${ }^{1} \mathrm{H}$ dimension. ${ }^{1} \mathrm{H}$ FID signals were truncated to $15 \mathrm{~ms}$, which ensures a minimal impact on measured linewidths. All spectra were analyzed using NMRFAM-Sparky [60]. Linewidths were estimated using a built-in utility, and report on full width at half-height of peaks centered at the maximum intensity. No peak fitting nor integration was applied due to common deviation from a Lorentzian shape.

\section{Shimming, magnet stability and magic-angle adjustment}

Probe shimming was performed using a sample of adamantane, where about $5 \mathrm{~Hz}$ linewidth was achieved in the ${ }^{13} \mathrm{C}$ spectrum. Independently, field homogeneity was verified to be less than $20 \mathrm{~Hz}$ using a residual ${ }^{1} \mathrm{H}$ methyl resonance in a rotor filled with a liquid ${ }^{2} \mathrm{H}$-methanol $\left(\mathrm{CD}_{3} \mathrm{OD}\right)$. This was repeated before a series of measurements for every protein sample.

Magic-angle was verified or adjusted at every MAS rate after stabilization of conditions (rotation rate and temperature) to ensure maximum ${ }^{1} \mathrm{H}^{\mathrm{N}}$ coherence lifetime and thus optimal resolution in ${ }^{1} \mathrm{H}$ dimension. This was monitored as intensity of $1 \mathrm{D}{ }^{1} \mathrm{H}$ spectrum acquired with ${ }^{15} \mathrm{~N}-\mathrm{CP}-\mathrm{HSQC}$ pulse sequence with an appended ${ }^{1} \mathrm{H}$ echo of a fixed duration of approximately $\mathrm{T}_{2}$.

Data were acquired without the use of a lock. The impact of $B_{0}$ field stability during experiments was monitored using 1D ${ }^{1} \mathrm{H}$ spectra, and, due to short total acquisition time, has negligible effect on resolution of acquired 2D spectra (less than $10 \mathrm{~Hz}$ drift). 


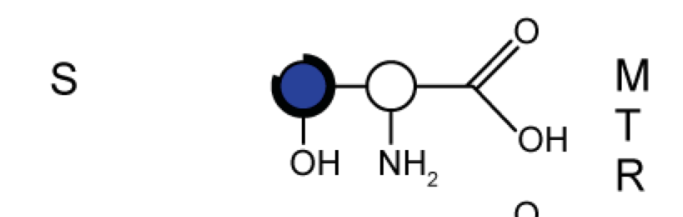<smiles>[R]c1ccc(-c2ccc(C(=O)O)c(N)c2)cc1</smiles>

${ }^{A}$
${ }^{C} W$
${ }_{D}$
${ }_{N}$
$Y$<smiles>NC(=O)OC(=O)O</smiles>
V<smiles>NC(OC(=O)O)C(=O)O</smiles>

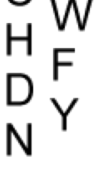<smiles>[R]OC(N)C(=O)O</smiles><smiles>[LiH]</smiles>

$\mathrm{E}$
$\mathrm{Q}$
$\mathrm{P}$<smiles>[R]Oc1ccc(C(N)C(=O)O)cc1</smiles>

G<smiles>NC(=O)C(=O)O</smiles>

K<smiles>NOC(=O)OOC(=O)O</smiles><smiles>NOC(O)COc1cc(OC(N)=O)cc(OCC(=O)O)c1OCC(=O)O</smiles>

Fig. 8. Schematic representation of ${ }^{1} \mathrm{H}$ dilution by inverse fractional deuteration, based on biosynthetic pathway analysis and experimental data on expression in E. coli BL21(DE3) cells reported by Medeiros-Silva et al. [39]. The degree of ${ }^{2} \mathrm{H}$ incorporation is illustrated by black rings of growing angular width and blue circles of increasing intensity: 0 to 10\% (white), 11 to $30 \%$ (light blue), 31 to $50 \%$ (medium blue), more than $51 \%$ (dark blue).

\section{Acknowledgements}

The financial support from CNRS (IR-RMN FR3050 and Fondation pour la Chimie des Substances Naturelles), European Research Council (ERC) under the European Union's Horizon 2020 research and innovation programme (ERC-2015-CoG GA n ${ }^{\circ}$ 648974) and from People Programme of the European Union's FP7 (FP7- PEOPLE-2012-ITN n³17127 "pNMR") is gratefully acknowledged. J.S., K.J. and L.B.A. are supported by individual MSCA incoming fellowships (REA grant agreements $n^{\circ} 661799$ "COMPLEX-FAST-MAS", n661175 "virus-DNP-NMR", n624918 "MEM-MAS"). We thank the members of technical staff of ISA for assistance with NMR spectrometers. 

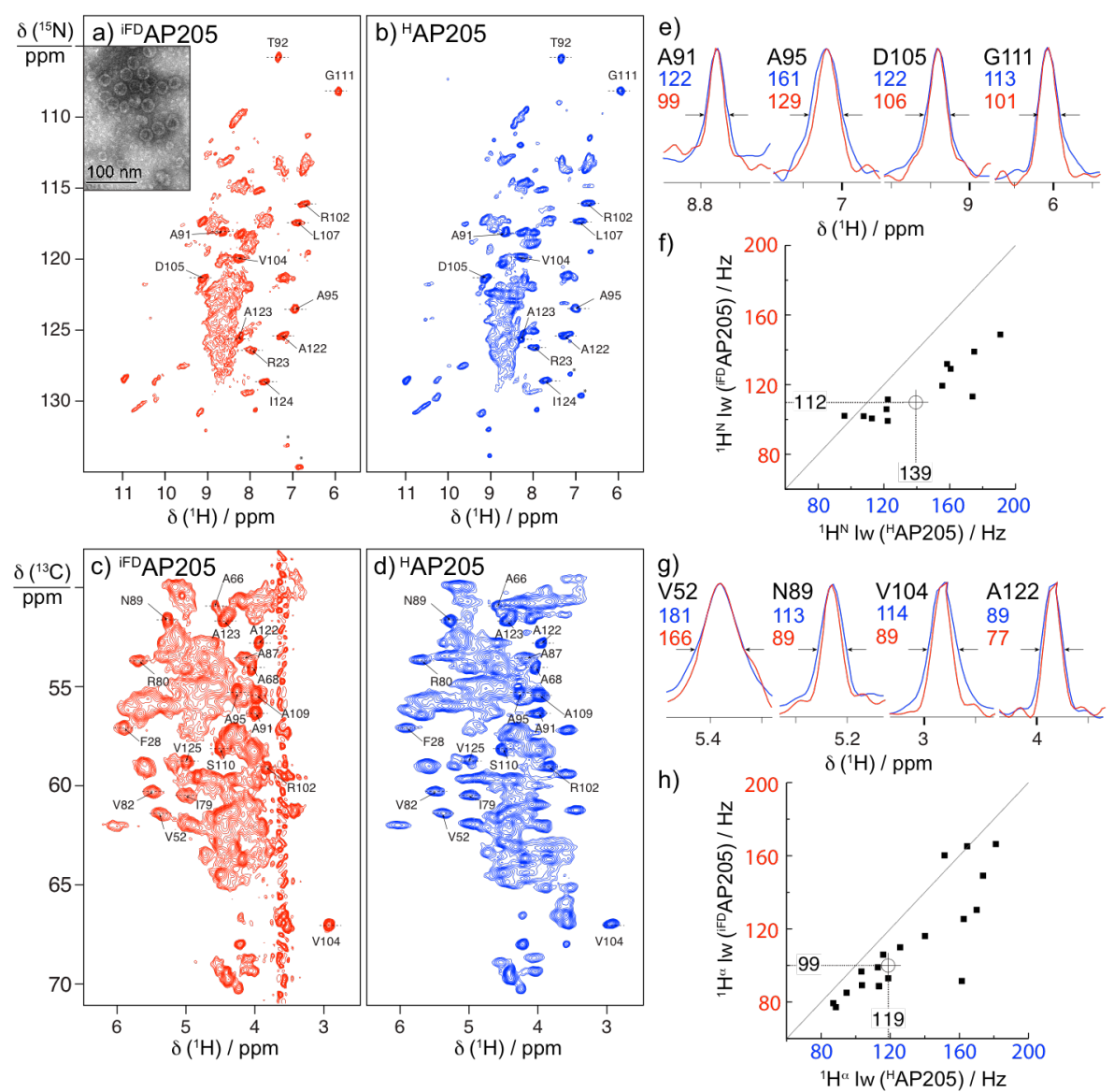

Fig. 9. ${ }^{15} \mathrm{~N}-\mathrm{CP}-\mathrm{HSQC}(\mathrm{a}, \mathrm{b})$ and $\mathrm{a}$-region of the ${ }^{13} \mathrm{C}-\mathrm{CP}-\mathrm{HSQC}(\mathrm{c}, \mathrm{d})$ of AP205 coat protein recorded on a $1 \mathrm{GHz}$ spectrometer and $100 \mathrm{kHz}$ MAS. Compared are the spectra of ${ }^{\mathrm{iFD}} \mathrm{AP} 205$ (a,c; red contours) and ${ }^{\mathrm{H}} \mathrm{AP} 205$ (b, d; blue contours). 12 and 18 isolated intense resonances for which ${ }^{1} \mathrm{H}$ linewidths were evaluated are labeled in (a-d). Representative ${ }^{1} \mathrm{H}$ cross-sections from ${ }^{15} \mathrm{~N}-(\mathrm{e})$ or ${ }^{13} \mathrm{C}-\mathrm{CP}-\mathrm{HSQC}(\mathrm{g})$. Linewidths for fully-protonated (in blue) and iFD samples (in red) are indicated below residue names (in Hertz). Comparison of ${ }^{1} \mathrm{H}^{\mathrm{N}}$ (f) and ${ }^{1} \mathrm{Ha}$ (h) linewidths between fully protonated and iFD samples. The median of linewidths is denoted by a crossed open circle and reported next to the respective axis. The contour levels are increasing exponentially with a multiplier of 1.2, and the lowest contour was normalized between spectra ( $a$ and b; $c$ and d) with respect to the average intensity of all isolated peaks to properly reflect linewidths.

\section{References}

[1] G. Bodenhausen, D.J. Ruben, Natural abundance nitrogen-15 NMR by enhanced heteronuclear spectroscopy, Chem. Phys. Lett. 69 (1980) 185-189.

[2] Y. Ishii, J.P. Yesinowski, R. Tycko, Sensitivity Enhancement in Solid-State 13C NMR of Synthetic Polymers and Biopolymers by $1 \mathrm{H}$ NMR Detection with High-Speed Magic Angle Spinning, J. Am. Chem. Soc. 123 (2001) 2921-2922.

[3] M.M. Maricq, J.S. Waugh, NMR in rotating solids, J. Chem. Phys. 70 (1979) 3300-3316.

[4] A.E. McDermott, F.J. Creuzet, A.C. Kolbert, R.G. Griffin, High-resolution magic-angle-spinning NMR spectra of protons in deuterated solids, J. Magn. Reson. 98 (1992) 408-413.

[5] L. Zheng, K.W. Fishbein, R.G. Griffin, J. Herzfeld, Two-dimensional solid-state proton NMR and proton exchange, J. Am. Chem. Soc. 115 (1993) 6254-6261.

[6] B. Reif, C.P. Jaroniec, C.M. Rienstra, M. Hohwy, R.G. Griffin, 1H-1H MAS correlation spectroscopy and distance measurements in a deuterated peptide, J. Magn. Reson. 151 (2001) 320-327.

[7] V. Chevelkov, B.J. van Rossum, F. Castellani, K. Rehbein, A. Diehl, M. Hohwy, S. Steuernagel, F. Engelke, H. Oschkinat, B. Reif, $1 \mathrm{H}$ detection in MAS solid-state NMR spectroscopy of biomacromolecules employing pulsed field gradients for residual solvent suppression, J. Am. Chem. Soc. 125 (2003) 7788-7789. 
[8] E.K. Paulson, C.R. Morcombe, V. Gaponenko, B. Dancheck, R.A. Byrd, K.W. Zilm, Sensitive high resolution inverse detection NMR spectroscopy of proteins in the solid state, J. Am. Chem. Soc. 125 (2003) 15831-15836.

[9] V. Chevelkov, K. Rehbein, A. Diehl, B. Reif, Ultrahigh resolution in proton solid-state NMR spectroscopy at high levels of deuteration, Angew. Chem. Int. Ed. Engl. 45 (2006) 3878-3881.

[10] D.H. Zhou, D.T. Graesser, W.T. Franks, C.M. Rienstra, Sensitivity and resolution in proton solidstate NMR at intermediate deuteration levels: Quantitative linewidth characterization and applications to correlation spectroscopy, J. Magn. Reson. 178 (2006) 297-307.

[11] Ü. Akbey, S. Lange, W.T. Franks, R. Linser, K. Rehbein, A. Diehl, B.-J. van Rossum, B. Reif, H. Oschkinat, Optimum Levels of Exchangeable Protons in Perdeuterated Proteins for Proton Detection in MAS Solid-State NMR Spectroscopy, J. Biomol. NMR 46 (2010) 67-73.

[12] A. Samoson, T. Tuherm, Z. Gan, High-field high-speed MAS resolution enhancement in 1H NMR spectroscopy of solids, Solid State Nucl Magn Reson 20 (2001) 130-6.

[13] L.B. Andreas, T. Le Marchand, K. Jaudzems, G. Pintacuda, High-resolution proton-detected NMR of proteins at very fast MAS, J. Magn. Reson. 253 (2015) 36-49.

[14] A. Böckmann, M. Ernst, B.H. Meier, Spinning proteins, the faster, the better?, J. Magn. Reson. 253 (2015) 71-79.

[15] J.R. Lewandowski, J.N. Dumez, Ü. Akbey, S. Lange, L. Emsley, H. Oschkinat, Enhanced resolution and coherence lifetimes in the solid-state NMR spectroscopy of perdeuterated proteins under ultrafast Magic-Angle Spinning, J. Chem. Phys. Lett. 2 (2011) 2205-2211.

[16] M.J. Knight, A.L. Webber, A.J. Pell, P. Guerry, E. Barbet-Massin, I. Bertini, I.C. Felli, L. Gonnelli, R. Pierattelli, L. Emsley, A. Lesage, T. Herrmann, G. Pintacuda, Fast resonance assignment and fold determination of human superoxide dismutase by high-resolution proton-detected solid-state MAS NMR spectroscopy, Angew. Chem. Int. Ed. Engl. 50 (2011) 11697-11701.

[17] A.J. Nieuwkoop, W.T. Franks, K. Rehbein, A. Diehl, Ü. Akbey, F. Engelke, L. Emsley, G. Pintacuda, H. Oschkinat, Sensitivity and resolution of proton detected spectra of a deuterated protein at 40 and $60 \mathrm{kHz}$ magic-angle-spinning, J. Biomol. NMR 61 (2015) 161-171.

[18] V. Agarwal, S. Penzel, K. Szekely, R. Cadalbert, E. Testori, A. Oss, J. Past, A. Samoson, M. Ernst, A. Böckmann, B.H. Meier, De Novo 3D Structure Determination from Sub-milligram Protein Samples by Solid-State 100 kHz MAS NMR Spectroscopy, Angew. Chem. Int. Ed. 53 (2014) 1225312256.

[19] J.M. Lamley, D. luga, C. Öster, H.-J. Sass, M. Rogowski, A. Oss, J. Past, A. Reinhold, S. Grzesiek, A. Samoson, J.R. Lewandowski, Solid-State NMR of a Protein in a Precipitated Complex with a Full-Length Antibody, J. Am. Chem. Soc. 136 (2014) 16800-16806.

[20] L.B. Andreas, J. Stanek, T. Le Marchand, A. Bertarello, D. Cala-De Paepe, D. Lalli, M. Krejčíková, C. Doyen, C. Öster, B. Knott, S. Wegner, F. Engelke, I.C. Felli, R. Pierattelli, N.E. Dixon, L. Emsley, T. Herrmann, G. Pintacuda, Protein residue linking in a single spectrum for magic-angle spinning NMR assignment, J. Biomol. NMR 62 (2015) 253-61.

[21] V. Agarwal, B. Reif, Residual methyl protonation in perdeuterated proteins for multi-dimensional correlation experiments in MAS solid-state NMR spectroscopy, J. Magn. Reson. 194 (2008) 16-24.

[22] V. Agarwal, A. Diehl, N. Skrynnikov, B. Reif, High resolution $1 \mathrm{H}$ detected $1 \mathrm{H}, 13 \mathrm{C}$ correlation spectra in MAS solid-state NMR using deuterated proteins with selective $1 \mathrm{H}, 2 \mathrm{H}$ isotopic labeling of methyl groups, J. Am. Chem. Soc. 128 (2006) 12620-12621.

[23] S. Asami, P. Schmieder, B. Reif, High resolution 1H-detected solid-state NMR spectroscopy of protein aliphatic resonances: access to tertiary structure information, J. Am. Chem. Soc. 132 (2010) 15133-15135.

[24] S. Asami, K. Szekely, P. Schanda, B.H. Meier, B. Reif, Optimal degree of protonation for (1)H detection of aliphatic sites in randomly deuterated proteins as a function of the MAS frequency, $\mathrm{J}$. Biomol. NMR 54 (2012) 155-168.

[25] D. Mance, T. Sinnige, M. Kaplan, S. Narasimhan, M. Daniels, K. Houben, M. Baldus, M. Weingarth, An Efficient Labelling Approach to Harness Backbone and Side-Chain Protons in (1) $\mathrm{H}-$ Detected Solid-State NMR Spectroscopy, Angew. Chem. Int. Ed. Engl. 54 (2015) 15799-15803.

[26] K.H. Gardner, M.K. Rosen, L.E. Kay, Global folds of highly deuterated, methyl-protonated proteins by multidimensional NMR, Biochemistry 36 (1997) 1389-1401.

[27] N.K. Goto, K.H. Gardner, G.A. Mueller, R.C. Willis, L.E. Kay, A robust and cost-effective method for the production of Val, Leu, Ile (delta 1) methyl-protonated $15 \mathrm{~N}-, 13 \mathrm{C}-, 2 \mathrm{H}$-labeled proteins, J. Biomol. NMR 13 (1999) 369-374.

[28] P. Gans, O. Hamelin, R. Sounier, I. Ayala, M.A. Dura, C.D. Amero, M. Noirclerc-Savoye, B. Franzetti, M.J. Plevin, J. Boisbouvier, Stereospecific isotopic labeling of methyl groups for NMR 
spectroscopic studies of high-molecular-weight proteins, Angew. Chem. Int. Ed. Engl. 49 (2010) 19581962.

[29] M. Huber, S. Hiller, P. Schanda, M. Ernst, A. Böckmann, R. Verel, B.H. Meier, A proton-detected 4D solid-state NMR experiment for protein structure determination, ChemPhysChem 12 (2011) 915918.

[30] V. Kurauskas, E. Crublet, P. Macek, R. Kerfah, D.F. Gauto, J. Boisbouvier, P. Schanda, Sensitive proton-detected solid-state NMR spectroscopy of large proteins with selective $\mathrm{CH} 3$ labelling: application to the 50 S ribosome subunit, Chem. Commun. 52 (2016) 9558-9561.

[31] R. Linser, B. Bardiaux, V. Higman, U. Fink, B. Reif, Structure calculation from unambiguous longrange amide and methyl $1 \mathrm{H}-1 \mathrm{H}$ distance restraints for a microcrystalline protein with MAS solid-state NMR spectroscopy, J. Am. Chem. Soc. 133 (2011) 5905-5912.

[32] M. Kainosho, T. Torizawa, Y. Iwashita, T. Terauchi, A. Mei Ono, P. Güntert, Optimal isotope labelling for NMR protein structure determinations, Nature 440 (2006) 52-57.

[33] H. Takahashi, M. Kainosho, H. Akutsu, T. Fujiwara, $1 \mathrm{H}$-detected $1 \mathrm{H}-1 \mathrm{H}$ correlation spectroscopy of a stereo-array isotope labeled amino acid under fast magic-angle spinning, J. Magn. Reson. 203 (2010) 253-256.

[34] S. Wang, S. Parthasarathy, Y. Nishiyama, Y. Endo, T. Nemoto, K. Yamauchi, T. Asakura, M. Takeda, T. Terauchi, M. Kainosho, Y. Ishii, Nano-mole scale side-chain signal assignment by $1 \mathrm{H}-$ detected protein solid-state NMR by ultra-fast magic-angle spinning and stereo-array isotope labeling, PLoS One 10 (2015) e0122714.

[35] T. Sinnige, M. Daniëls, M. Baldus, M. Weingarth, Proton Clouds to measure long-range contacts between nonexchangeable side chain protons in solid-state NMR, J. Am. Chem. Soc. 136 (2014) $4452-4455$.

[36] L.B. Andreas, K. Jaudzems, J. Stanek, D. Lalli, A. Bertarello, T. Le Marchand, D. Cala-De Paepe, S. Kotelovica, I. Akopjana, B. Knott, S. Wegner, F. Engelke, A. Lesage, L. Emsley, K. Tars, T. Herrmann, G. Pintacuda, Structure of fully protonated proteins by proton-detected magic-angle spinning NMR, Proc. Natl. Acad. Sci. USA 113 (2016) 9187-9192.

[37] M.E. Ward, L. Shi, E. Lake, S. Krishnamurthy, H. Hutchins, L.S. Brown, V. Ladizhansky, Protondetected solid-state NMR reveals intramembrane polar networks in a seven-helical transmembrane protein proteorhodopsin, J. Am. Chem. Soc. 133 (2011) 17434-17443.

[38] J.H. Chill, J.M. Louis, C. Miller, A. Bax, NMR study of the tetrameric KcsA potassium channel in detergent micelles, Protein Sci. 15 (2006) 684-698.

[39] J. Medeiros-Silva, D. Mance, M. Daniels, S. Jekhmane, K. Houben, M. Baldus, M. Weingarth, 1HDetected Solid-State NMR Studies of Water-Inaccessible Proteins In Vitro and In Situ, Angew. Chem. Int. Ed. Engl. 55 (2016) 13606-13610.

[40] D.H. Zhou, G. Shah, M. Cormos, C. Mullen, D. Sandoz, C.M. Rienstra, Proton-detected solidstate NMR Spectroscopy of fully protonated proteins at $40 \mathrm{kHz}$ magic-angle spinning, J. Am. Chem. Soc. 129 (2007) 11791-11801.

[41] A. Marchetti, S. Jehle, M. Felletti, M.J. Knight, Y. Wang, Z.Q. Xu, A.Y. Park, G. Otting, A. Lesage, L. Emsley, N.E. Dixon, G. Pintacuda, Backbone assignment of fully protonated solid proteins by $1 \mathrm{H}$ detection and ultrafast Magic-Angle-Spinning NMR spectroscopy, Angew. Chemie Int. Ed. Engl. 51 (2012) 10756-10759.

[42] S.K. Vasa, P. Rovo, K. Giller, S. Becker, R. Linser, Access to aliphatic protons as reporters in non-deuterated proteins by solid-state NMR, Phys. Chem. Chem. Phys. 18 (2016) 8359-8363.

[43] K.H. Mroue, Y. Nishiyama, M.K. Pandey, B. Gong, E. McNerny, D.H. Kohn, M.D. Morris, A. Ramamoorthy, Proton-Detected Solid-State NMR Spectroscopy of Bone with Ultrafast Magic Angle Spinning, Sci. Rep. 5 (2015) 11991.

[44] Y. Nishiyama, Fast magic-angle sample spinning solid-state NMR at $60-100 \mathrm{kHz}$ for natural abundance samples, Solid State Nucl. Magn. Reson. 78 (2016) 24-36.

[45] M.K. Pandey, Y. Nishiyama, Determination of NH proton chemical shift anisotropy with (14) $\mathrm{N}-(1) \mathrm{H}$ heteronuclear decoupling using ultrafast magic angle spinning solid-state NMR, J. Magn. Reson. 261 (2015) 133-140.

[46] J. Stanek, L.B. Andreas, K. Jaudzems, D. Cala, D. Lalli, A. Bertarello, T. Schubeis, I. Akopjana, S. Kotelovica, K. Tars, A. Pica, S. Leone, D. Picone, Z.-Q. Xu, N.E. Dixon, D. Martinez, M. Berbon, N. El Mammeri, A. Noubhani, S. Saupe, B. Habenstein, A. Loquet, G. Pintacuda, NMR spectroscopic assignment of backbone and side - chain protons in fully protonated proteins: microcrystals, sedimented assemblies, and amyloid fibrils, Angew. Chem. Int. Ed. 128 (2016) 15730-15735.

[47] H.L.F. Schmidt, L.J. Sperling, Y.G. Gao, B.J. Wylie, J.M. Boettcher, S.R. Wilson, C.M. Rienstra, Crystal polymorphism of protein GB1 examined by solid-state NMR spectroscopy and X-Ray diffraction, J. Phys. Chem. B 111 (2007) 14362-14369. 
[48] H.R. Dannatt, M. Felletti, S. Jehle, Y. Wang, L. Emsley, N.E. Dixon, A. Lesage, G. Pintacuda, Weak and Transient Protein Interactions Determined by Solid-State NMR, Angew Chem Int Ed Engl 55 (2016) 6638-41.

[49] E. Barbet-Massin, A.J. Pell, K. Jaudzems, W.T. Franks, J.S. Retel, S. Kotelovica, I. Akopjana, K. Tars, L. Emsley, H. Oschkinat, A. Lesage, G. Pintacuda, Out-and-back 13C-13C scalar transfers in protein resonance assignment by proton-detected solid-state NMR under ultra-fast MAS, J. Biomol. NMR 56 (2013) 379-386.

[50] S.H. van den Worm, R.I. Koning, H.J. Warmenhoven, H.K. Koerten, J. van Duin, Cryo electron microscopy reconstructions of the Leviviridae unveil the densest icosahedral RNA packing possible, J. Mol. Biol. 363 (2006) 858-865.

[51] M. Shishovs, J. Rumnieks, C. Diebolder, K. Jaudzems, L.B. Andreas, J. Stanek, A. Kazaks, S. Kotelovica, I. Akopjana, G. Pintacuda, R.I. Koning, K. Tars, Structure of AP205 Coat Protein Reveals Circular Permutation in ssRNA Bacteriophages, J. Mol. Biol. 428 (2016) 4267-4279.

[52] E. Barbet-Massin, A.J. Pell, J.S. Retel, L.B. Andreas, K. Jaudzems, W.T. Franks, A.J. Nieuwkoop, M. Hiller, V. Higman, P. Guerry, A. Bertarello, M.J. Knight, M. Felletti, T. Le Marchand, S. Kotelovica, I. Akopjana, K. Tars, M. Stoppini, V. Bellotti, M. Bolognesi, S. Ricagno, J.J. Chou, R.G. Griffin, H. Oschkinat, A. Lesage, L. Emsley, T. Herrmann, G. Pintacuda, Rapid Proton-Detected NMR Assignment for Proteins with Fast Magic Angle Spinning, J. Am. Chem. Soc. 136 (2014) 12489-12497. [53] W.T. Franks, D.H. Zhou, B.J. Wylie, B.G. Money, D.T. Graesser, H.L. Frericks, G. Sahota, C.M. Rienstra, Magic-angle spinning solid-state NMR spectroscopy of the $\beta 1$ immunoglobulin binding domain of protein G (GB1): N-15 and C-13 chemical shift assignments and conformational analysis, J. Am. Chem. Soc. 127 (2005) 12291-12305.

[54] I. Bertini, F. Engelke, L. Gonnelli, B. Knott, C. Luchinat, D. Osen, E. Ravera, On the use of ultracentrifugal devices for sedimented solute NMR, J. Biomol. NMR 54 (2012) 123-127.

[55] C. Gardiennet, A.K. Schutz, A. Hunkeler, B. Kunert, L. Terradot, A. Böckmann, B.H. Meier, A sedimented sample of a $59 \mathrm{kDa}$ dodecameric helicase yields high-resolution solid-state NMR spectra, Angew. Chem. Int. Ed. Engl. 51 (2012) 7855-7858.

[56] D.H. Zhou, J.J. Shea, A.J. Nieuwkoop, W.T. Franks, B.J. Wylie, C. Mullen, D. Sandoz, C.M. Rienstra, Solid-state protein-structure determination with proton-detected triple-resonance 3D magicangle-spinning NMR spectroscopy, Angew. Chem. Int. Ed. Engl. 46 (2007) 8380-8383.

[57] J.R. Lewandowski, J. Sein, H.J. Sass, S. Grzesiek, M. Blackledge, L. Emsley, Measurement of site-specific $13 \mathrm{C}$ spin-lattice relaxation in a crystalline protein, J. Am. Chem. Soc. 132 (2010) $8252-$ 8254.

[58] D.H. Zhou, C.M. Rienstra, High-performance solvent suppression for proton detected solid-state NMR, J. Magn. Reson. 192 (2008) 167-172.

[59] H. Geen, R. Freeman, Band-Selective Radiofrequency Pulses, J. Magn. Reson. 93 (1991) 93141.

[60] W. Lee, M. Tonelli, J.L. Markley, NMRFAM-SPARKY: enhanced software for biomolecular NMR spectroscopy, Bioinformatics 31 (2015) 1325-1327. 